[Article]

\title{
$\mathbf{C}_{1}-\mathbf{C}_{2}$ 燃料燃烧机理的框架简化
}

\author{
李树豪 ${ }^{1}$ 李 瑞 $^{1} \quad$ 郭俊江 $^{2}$ 谈宁馨 ${ }^{2}$ 王 繁 ${ }^{3, *}$ 李象远 ${ }^{2}$

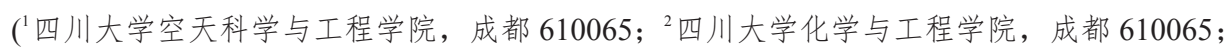 \\ ${ }^{3}$ 四川大学原子与分子物理研究所, 成都 610065)
}

\begin{abstract}
摘要: 采用六种直接关系图类(DRG)方法对包含 253 个物种和 1542 个反应的AramcoMech 1.3 机理进行简 化, 并通过对所得到的六种简化机理取交集, 最终得到包含 81 个物种和 497 个反应的框架机理。所得 81 个 物种框架机理的点火延迟时间最大误差与其简化方法得到的框架机理最大误差相比并没有显著增加; 这表明 从不同简化方法的框架机理结果取交集可以有效去除冗余物种。基于 81 个物种框架机理模拟的双组分混合 燃料的点火延迟时间与详细机理机理结果吻合很好。同时该框架机理在不同反应器中的模拟结果验证了温 度、物种浓度分布和火焰等燃烧特性。元素流动分析结果表明, 81 个物种框架机理精确地再现了详细机理的 燃烧反应路径。保留了详细机理的所有重要反应路径和层级结构, 能够很好地再现 $\mathrm{C}_{1}-\mathrm{C}_{2}$ 燃料的各种燃烧特 性。因此，基于该 81 个物种框架机理可作为核心机理用于发展大分子烃类或含氧燃料的燃烧机理。
\end{abstract}

关键词: 燃烧机理; 框架简化; 直接关系图方法; 交集方法

中图分类号: 0643

\section{Skeletal Kinetic Model Generation for the Combustion of $C_{1}-C_{2}$ Fuels}

\author{
LI Shu-Hao ${ }^{1} \quad$ LI Rui $\quad$ GUO Jun-Jiang ${ }^{2} \quad$ TAN Ning-Xin $^{2} \quad$ WANG Fan ${ }^{3, *} \quad$ LI Xiang-Yuan ${ }^{2}$ \\ ('School of Aeronautics \& Astronautics, Sichuan University, Chengdu 610065, P. R. China; \\ ${ }^{2}$ School of Chemical Engineering, Sichuan University, Chengdu 610065, P. R. China; \\ ${ }^{3}$ Institute of Atomic and Molecular Physics, Sichuan University, Chengdu 610065, P. R. China)
}

\begin{abstract}
The AramcoMech 1.3 mechanism, containing 253 species and 1542 reactions for oxidation of hydrocarbon and oxygenated $C_{1}-C_{2}$ fuels, is reduced with six direct relation graph (DRG)-related methods. The final skeletal mechanism with 81 species and 497 reactions is achieved from the intersection of the resulting skeletal mechanisms obtained with these DRG-related methods. The maximum error for the ignition delay times with this 81-species mechanism does not increase significantly compared with that obtained for the other skeletal mechanisms. This shows that the intersection of skeletal mechanisms from various mechanism reduction methods can effectively remove the redundant species. Ignition delay times of two-component mixtures with the skeletal mechanism also agree very well with those of the detailed mechanism. The skeletal mechanism has also been validated against the detailed mechanism using many other combustion characters of the involved fuels in different reactors and flames. Results from the element flux analysis demonstrate that the reaction paths for these fuels with the detailed mechanism can be reproduced accurately with the 81-species skeletal mechanism. All the important reaction paths are thus retained in the 81-species mechanism. All these results show that the skeletal mechanism is able to provide the combustion properties of $\mathrm{C}_{1}-\mathrm{C}_{2}$ fuels that are in good agreement with those of the detailed mechanism. The 81-species skeletal mechanism can be employed as a reaction base for developing mechanisms of other large hydrocarbon or oxygenated fuels.
\end{abstract}

Received: February 24, 2016; Revised: April 7, 2016; Published on Web: April 8, 2016.

${ }^{*}$ Corresponding author. Email: wangf44@gmail.com; Tel: +86-28-85403537.

The project was supported by the National Natural Science Foundation of China (91441132).

国家自然科学基金(91441132)资助项目

(c) Editorial office of Acta Physico-Chimica Sinica 
Key Words: Combustion mechanism; Skeletal reduction; Direct relation graph method; Intersection method

\section{Introduction}

Detailed oxidation kinetics of $\mathrm{C}_{1}-\mathrm{C}_{2}$ species, such as methane, ethane, ethylene, and acetylene, as well as oxygenated fuels such as formaldehyde, acetaldehyde, methanol, ethanol, plays a key role in understanding oxidation of practical hydrocarbon and oxygenated fuels ${ }^{1,2}$. Large hydrocarbon radicals usually undergo fast $\beta$-scission reactions to form these small molecules and combustion properties of large hydrocarbon fuels depend critically on oxidation processes of small molecules ${ }^{3-5}$. Oxidation kinetics of $\mathrm{C}_{1}-\mathrm{C}_{2}$ species is thus often adopted as reaction base or core mechanism in generation of oxidation mechanisms for large hydrocarbon or oxygenated fuels. Reliability of the obtained oxidation mechanism is closely related to quality of the employed oxidation kinetics for $\mathrm{C}_{1}-\mathrm{C}_{2}$ species. In addition, methane is the main component for natural gas ${ }^{6}$; ethylene is an important intermediate of hydrocarbon fuel oxidation; ethanol is usually blended with gasoline at a certain proportion to produce ethanol gasoline and to improve performance of regular gasoline and reduce emission of major pollutants. Oxidation kinetics of $\mathrm{C}_{1}-\mathrm{C}_{2}$ fuels itself is thus important in practical engineering application.

Detailed oxidation kinetics for these simple fuels has been investigated extensively by many groups. For example, combustion kinetics for $\mathrm{C}_{1}-\mathrm{C}_{3}$ fuels ${ }^{7}, \mathrm{C}_{1}-\mathrm{C}_{4}$ fuels ${ }^{8}$, ethanol ${ }^{9}$ have been developed in Lawrence Livermore National Laboratory (LLNL) in 1998, 1998, and 1999, respectively. Qin et al. ${ }^{10}$ developed a combustion model for $\mathrm{C}_{1}-\mathrm{C}_{3}$ fuels in 2000. Combustion model for ethylene applicable to both low and high pressures was proposed by Carriere et al. ${ }^{11}$ in 2002. The San Diego Mechanism was designed to predict combustion properties of $\mathrm{C}_{1}-\mathrm{C}_{3}$ fuels by Williams et al. ${ }^{12,13}$. USC Mech II mechanism was developed to predict high temperature combustion of $\mathrm{C}_{1}-\mathrm{C}_{4}$ fuels in $2007^{14}$, and the Politecnico di Milano CRECK mechanism was proposed to simulate oxidation of $\mathrm{C}_{1}-\mathrm{C}_{3}$ fuels in $2012^{15}$. Combustion mechanism for $\mathrm{C}_{1}-\mathrm{C}_{2}$ oxygenated fuels was developed by Vourliotakis et al. ${ }^{16}$ in 2015 . These mechanisms have evolved somewhat differently, but also quite similarly. Different versions of the same mechanism involve similar reactions but with different rate constants. ${ }^{1}$ Some of these kinetics mechanisms focused on combustion characteristics of a single or two-component fuels, such as Carriere's ethylene oxidation mechanism ${ }^{11}$, the methane/ ethane mechanism of Barbé et al. ${ }^{17}$ and the methane mechanism developed in Leeds etc. ${ }^{18,19}$ However, practical fuels are multicomponent mixture in most cases. For example, natural gas is composed of a small amount of carbon monoxide, ethane, propane etc., besides methane. These mechanisms are thus insufficient for combustion simulation of practical fuels or play the role as core mechanisms. Herein, the AramcoMech 1.3 mechanism has been developed by Metcalfe et al. ${ }^{1}$ in 2013. Rate constants employed in this mechanism are taken from the most recent accurate measurements or calculations, and otherwise estimated by requiring that simulation results can accurately reproduce a range of targets such as ignition delay time $(\tau)$, flame speeds, and speciation profiles in flow- and jet-stirred reactors as well as in burner-stabilized flames. Successes of AramcoMech 1.3 lie in comprehensive range of its validated applicability. It is also among the best kinetic models in predicting basic combustion properties of $\mathrm{C}_{1}-\mathrm{C}_{2}$ hydrocarbon and oxygenated fuels ${ }^{1}$. The detailed AramcoMech 1.3 model is composed of 253 species and 1542 reactions. Kinetic models for other large hydrocarbon or oxygenated fuels using AramcoMech 1.3 as core mechanism will be even larger in size. In fact, the AramcoMech 1.3 model itself is too large to be incorporated in two- or three-dimensional combustion simulation of $\mathrm{C}_{1}-\mathrm{C}_{2}$ species using computational fluid dynamics (CFD). Therefore, reduction in size of the core mechanism while retaining its predictive capabilities will benefit mechanism generation of large fuels and facilitate its application in combustion simulation of small $\mathrm{C}_{1}-\mathrm{C}_{2}$ species. Moreover, a reduced mechanism will also ease sensitivity analysis and reaction path analysis.

Much progress has been achieved in mechanism reduction and many mechanism reduction methods have been proposed. They served as powerful means in application of chemical kinetics in CFD simulations. Mechanism reduction can be classified into two classes: skeletal reduction and global reduction. Skeletal reduction is usually the first step in mechanism reduction, which removes unimportant species and reactions from the detailed mechanism. Global reduction is employed to reduce stiffness of the mechanism based on time-scale analysis on the involved reactions and it can be applied more effectively after skeletal reduction.

Skeletal reduction methods include sensitivity analysis, ${ }^{20}$ level of importance (LOI) $)^{21}$, and directed relation graph (DRG) ${ }^{22}$ etc. DRG proposed by $\mathrm{Lu}$ and $\mathrm{Law}^{23}$ is one of the most popular skeletal reduction methods due to its simplicity and high efficiency. Other closely-related reduction methods have also been developed, such as DRG with error propagation (DRGEP) ${ }^{24}$, path flux analysis $(\mathrm{PFA})^{25}$, revised-DRG ${ }^{26}$, DRG-aided sensitivity analysis (DRGASA) ${ }^{27}$, DRGEP with sensitivity analysis $(\text { DRGEPASA })^{28}$, as well as flux path tree (FPT $)^{29}$. On the other hand, quasi steady state approximation (QSSA $)^{30}$, computational singular perturbation method (CSP) ${ }^{31,32}$ and intrinsic low dimensional manifold (ILDM) ${ }^{33}$ are currently the main global reduction methods.

In this paper, several DRG related skeletal reduction methods, i.e., the original DRG, a revised-DRG, PFA, as well as error propagation methods based on these methods are adopted to reduce the AramcoMech 1.3 mechanism. Firstly, the employed mechanism reduction methods as well as analysis methods are introduced. Secondly, simulation results of skeletal mechanism are compared with those of the detailed mechanism, and reaction paths as well as sensitivity coefficients are analyzed with the skeletal mechanisms. Finally, expanded verifications are carried out to further validate the skeletal mechanism. 


\section{Mechanism reduction and analysis method \\ 2.1 Mechanism reduction methods}

To identify unimportant species, coupling between two species in detailed mechanism must be evaluated properly. In the original DRG method proposed by Lu and $\mathrm{Law}^{22}$ in 2005 , coupling between species A and species B, or interaction coefficient is defined as the following:

$$
\begin{aligned}
& r_{\mathrm{AB}}^{\mathrm{DRG}}=\frac{\sum_{i=1, I}\left|v_{\mathrm{A}, i} \omega_{i} \delta_{\mathrm{B}}^{i}\right|}{\sum_{i=1, I}\left|v_{\mathrm{A}, i} \omega_{i}\right|} \\
& \delta_{\mathrm{B}}^{i}=\left\{\begin{array}{l}
1, \text { if the } i \text { th elementary reaction involves species } \mathrm{B} \\
0, \text { otherwise }
\end{array}\right.
\end{aligned}
$$

where $v_{\mathrm{A}, i}$ is the net stoichiometric coefficient of species $\mathrm{A}$ in the $i$ th reaction and $\omega_{i}$ is the net reaction rate of the $i$ th reaction, $I$ is the number of reactions in a detailed mechanism. If $r_{\mathrm{AB}}$ is sufficiently large, eliminating species B will induce large error on net production or consumption rate of species A. B should thus be retained in the skeletal mechanism if $\mathrm{A}$ is an important species or a target species. A directed relation graph can be set up with each species represented by a vertex and a directed edge from A to B if $r_{\mathrm{AB}}$ is larger than a predefined threshold. Important species can be figured out through a search of this directed graph starting from a set of target species. Due to its simplicity and efficiency, DRG is nowadays one of the most popular methods in skeletal reduction $^{3,26}$.

A revised-DRG (r-DRG) method was suggested by Luo et al. ${ }^{26}$ in 2010. In their approach, the interaction coefficient $r_{\mathrm{AB}}$ was calculated from the largest element in the summation employed in Eq.(1) as the following:

$$
r_{\mathrm{AB}}^{\mathrm{r}-\mathrm{DRG}}=\frac{\max _{i}\left|v_{\mathrm{A}, i} \omega_{i} \delta_{\mathrm{B}}^{i}\right|}{\max _{i}\left|v_{\mathrm{A}, i} \omega_{i}\right|}
$$

Compared with the original DRG method, the revised-DRG method is more efficient in handling large isomer groups frequently encountered in combustion kinetics of biodiesel, such as lipids fuels. ${ }^{26}$

Sun et al..$^{25}$ introduced a path flux analysis (PFA) method in 2010 and coupling between two species is calculated in a more complicated way. Contributions to coupling coefficients due to production and consumption are evaluated separately in PFA. Direct coupling between two species is termed as "first generation coupling" and is calculated as the following in PFA:

$$
\begin{aligned}
& r_{\mathrm{AB}}^{\mathrm{pro}-1 \mathrm{st}}=\frac{P_{\mathrm{AB}}}{\max \left(P_{\mathrm{A}}, C_{\mathrm{A}}\right)} \\
& r_{\mathrm{AB}}^{\mathrm{con}-1 \mathrm{st}}=\frac{C_{\mathrm{AB}}}{\max \left(P_{\mathrm{A}}, C_{\mathrm{A}}\right)} \\
& P_{\mathrm{AB}}=\sum_{i=1, I} \max \left(v_{\mathrm{A}, i} \omega_{i} \delta_{\mathrm{B}}^{i}, 0\right), C_{\mathrm{AB}}=\sum_{i=1, I} \max \left(-v_{\mathrm{A}, i} \omega_{i} \delta_{\mathrm{B}}^{i}, 0\right) \\
& P_{\mathrm{A}}=\sum_{i=1, I} \max \left(v_{\mathrm{A}, i} \omega_{i}, 0\right), C_{\mathrm{A}}=\sum_{i=1, I} \max \left(-v_{\mathrm{A}, i} \omega_{i}, 0\right)
\end{aligned}
$$

Besides the first generation coupling, a second generation coupling, i.e. coupling between A and B via a third species (M), is also taken into considered in PFA. Similar to the first generation coupling, contributions to the second generation coupling from production and consumption are calculated separately:

$$
\begin{aligned}
& r_{\mathrm{AB}}^{\text {pro-2nd }}=\sum_{M_{i} \neq \mathrm{A}, \mathrm{B}} r_{\mathrm{AM}}^{\text {pro- } 1 \text { st }} r_{\mathrm{M}_{i} \mathrm{~B}}^{\mathrm{pro}-1 \mathrm{st}} \\
& r_{\mathrm{AB}}^{\text {con-2nd }}=\sum_{M_{i} \neq \mathrm{A}, \mathrm{B}} r_{\mathrm{AM}}^{\text {con-1st }} r_{\mathrm{M}_{i} \mathrm{~B}}^{\text {con } 1 \text { st }}
\end{aligned}
$$

The interaction coefficient $r_{\mathrm{AB}}$ in PFA method is defined as summation of the first- and second-generation coupling from both production and consumption as:

$$
r_{\mathrm{AB}}^{\mathrm{PFA}}=r_{\mathrm{AB}}^{\mathrm{pro}-1 \mathrm{st}}+r_{\mathrm{AB}}^{\mathrm{con}-1 \mathrm{st}}+r_{\mathrm{AB}}^{\mathrm{pro}-2 \mathrm{nd}}+r_{\mathrm{AB}}^{\mathrm{con}-2 \mathrm{nd}}
$$

By taking into consideration of indirect coupling between two species, PFA has been shown to be able to afford skeletal mechanisms with a smaller size compared with DRG given the same simulation error for combustion mechanisms of $n$-heptane and $n$ decane ${ }^{25}$. On the other hand, PFA is also more time-consuming than DRG in order to calculate the second generation coupling and this increase in computational effort of PFA becomes more pronounced in reduction of mechanisms with a large number of species $^{25,29}$.

To account for all possible indirect coupling between two species, Pepiot-Desjardins and $\mathrm{Pitsch}^{24}$ proposed the DRG with error propagation (DRGEP) method in 2008. A new interaction coefficient of $r_{\mathrm{AB}}$ was defined in DRGEP:

$$
r_{\mathrm{AB}}^{\mathrm{n}-\mathrm{DRG}}=\frac{\left|\sum_{i=1, I} v_{\mathrm{A}, i} \omega_{i} \delta_{\mathrm{B}}^{i}\right|}{\max \left(P_{\mathrm{A}}, C_{\mathrm{A}}\right)}
$$

$\mathrm{n}$ in n-DRG means new. Coupling between two species through a certain path $p$ that links species A and B is evaluated based on the following equation:

$$
r_{\mathrm{AB}, p}^{\mathrm{DRGEP}}=\prod_{i=1}^{n-1} r_{S_{i} S_{i+1}}^{\mathrm{n}-\mathrm{DRG}}
$$

with $S_{1}=\mathrm{A}, S_{n}=\mathrm{B}, S_{i}$ and $S_{i+1}$ being different intermediate species. The final expression of the interaction coefficient $R_{\mathrm{AB}}^{\mathrm{DRGP}}$ between species A and B is defined as the maximum value of the interaction coefficients among all possible paths:

$$
R_{\mathrm{AB}}^{\mathrm{DRGEP}}=\max _{\text {all paths } p}\left(r_{\mathrm{AB}, p}^{\mathrm{DRGEP}}\right)
$$

where $p$ represents each possible path.

One can readily extend this idea of "error propagation" to $r$ DRG and PFA approaches in a similar way. We proposed $r-$ DRGEP and PFA with error propagation (PFAEP) methods, where coupling between two species through a certain path is calculated using similar equations as in Eqs.(12) and (13).

It is rather difficult to achieve a skeletal mechanism containing only important species and performance of skeletal reduction methods depends on the detailed mechanism they are applied to. In practice, one usually tries different mechanism reduction methods and chooses the one that provides the smallest skeletal mechanism with a given simulation error. On the other hand, species included in all the achieved skeletal mechanisms from various reduction methods should be truly important. A mechanism from intersection of a set of skeletal mechanisms will contain less species $^{34}$, but one would expect that it will have a larger simulation error. In fact, Results of Wang ${ }^{34}$ and Li et al..$^{35}$ show that simulation error of the skeletal mechanism from intersection of a set of skeletal mechanisms does not increase significantly while the number of species in this mechanism can be reduced to some 
extent. In this work, the final skeletal mechanism is obtained based on intersection approach based on mechanisms from six direct relation graph related methods.

\subsection{Time-integrated element flux analysis}

Time-integrated element flux analysis provides a simple method to identify reaction paths connecting different species ${ }^{36,37}$. The method is briefly outlined as following. In a chemical system consisting of $K$ species and $I$ elementary reactions, we can use the following formula to calculate contribution of reaction $i$ to the total flow of element $\mathrm{E}$ (such as $\mathrm{C}, \mathrm{H}, \mathrm{O}$ ) from species A to B, as well as the proportion of the flow of element $\mathrm{E}$ from species $\mathrm{A}$ to $\mathrm{B}$ species in the total flow of this element from species A to all the other species:

$$
\begin{gathered}
E_{i, \mathrm{~A} \rightarrow \mathrm{B}}=\frac{\int_{0}^{\tau} \omega_{i}(t) \frac{N_{\mathrm{E}, \mathrm{A}} N_{\mathrm{E}, \mathrm{B}}}{N_{\mathrm{E}, i}} \mathrm{~d} t}{\int_{0}^{\tau} \sum_{i=1}^{I}\left(\omega_{i}(t) \frac{N_{\mathrm{E}, \mathrm{A}} N_{\mathrm{E}, \mathrm{B}}}{N_{\mathrm{E}, i}}\right) \mathrm{d} t} \\
E_{\mathrm{A} \rightarrow \mathrm{B}}=\frac{\int_{0}^{\tau} \sum_{i=1}^{I}\left(\omega_{i}(t) \frac{N_{\mathrm{E}, \mathrm{A}} N_{\mathrm{E}, \mathrm{B}}}{N_{\mathrm{E}, i}}\right) \mathrm{d} t}{\sum_{k}^{K}\left[\int_{0}^{\tau} \sum_{i=1}^{I}\left(\omega_{i}(t) \frac{N_{\mathrm{E}, \mathrm{A}} N_{\mathrm{E}, \mathrm{B}}}{N_{\mathrm{E}, i}}\right) \mathrm{d} t\right]}
\end{gathered}
$$

where $N_{\mathrm{E}, \mathrm{A}}, N_{\mathrm{E}, \mathrm{B}}$, and $N_{\mathrm{E}, i}$ refer to the number of element $\mathrm{E}$ in species $\mathrm{A}, \mathrm{B}$, and reaction $i$, respectively, $\tau$ is reaction time. The element flux analyses ${ }^{3}$ are implemented as post-processing programs based on SENKIN program ${ }^{38}$.

\section{Results and discussion}

\subsection{Mechanism reduction}

In the present work, the detailed AramcoMech 1.3 mechanism for combustion of $\mathrm{C}_{1}-\mathrm{C}_{2}$ hydrocarbon and oxygenated fuels containing 253 species and 1542 reactions is reduced using DRG, DRGEP, r-DRG, r-DRGEP, PFA, and PFAEP. Mechanism reductions are carried out with an automatic mechanism reduction program ReaxRed ${ }^{39}$, to generate skeletal mechanisms with a given simulation error. To achieve a skeletal mechanism that is able to describe ignition delay times of $\mathrm{CH}_{4}, \mathrm{CH}_{3} \mathrm{OH}, \mathrm{CH}_{2} \mathrm{O}, \mathrm{C}_{2} \mathrm{H}_{2}, \mathrm{C}_{2} \mathrm{H}_{4}$, $\mathrm{C}_{2} \mathrm{H}_{6}, \mathrm{C}_{2} \mathrm{H}_{5} \mathrm{OH}$, and $\mathrm{CH}_{3} \mathrm{CHO}$, auto-ignition processes with constant pressure in a homogeneous reactor for a mixture of these eight fuels with equal proportion are simulated with SENKIN ${ }^{37}$. Sampling points required in mechanism reduction are taken from simulation results near ignition time with pressure from $1.01 \times 10^{5}$ to $3.04 \times 10^{6} \mathrm{~Pa}$, equivalence ratio from 0.5 to 2.0 , and initial temperature from $800-1600 \mathrm{~K}$. H radical is selected as the target species in the employed reduction methods following Ref.26 since it is one of the most important species in combustion processes of all these fuels. Error of the achieved skeletal mechanisms is estimated using the absolute relative error on ignition delay time (error $=\left(\left|\tau_{\text {detailed }}-\tau_{\text {skeletal }}\right| / \tau_{\text {detailed }} \times 100 \%\right)$, which is defined as the time when an increase of $400 \mathrm{~K}$ in temperature occurs.

To achieve a skeletal mechanism that is able to play the role as reaction base for generation of other large hydrocarbon or oxygenated fuels, the maximum relative error of the resulting skeletal mechanism on ignition delay time is required to be less than $10 \%$ for these small fuels. Number of species retained in the skeletal mechanisms with these six reduction approaches is: 171 species and 1258 reactions with DRG, 119 species and 836 reactions with DRGEP, 131 species and 928 reactions with r-DRG, 85 species and 509 reactions with r-DRGEP, 176 species and 1295 reactions with PFA and 105 species and 722 reactions with PFAEP. One can see from this result that $r-D R G$ is able to provide skeletal mechanism with a smaller size than DRG and PFA for this mechanism. Furthermore, this mechanism can be reduced effectively using error-propagation method without scarifying accuracy. It is almost impossible to only retain important species in mechanism reduction and some redundant species will always exist. By taking intersection of these six skeletal mechanisms, or only keeping species appeared in all these six skeletal mechanisms, redundant species can be removed further. This intersection approach results in a skeletal mechanism with 81 species and 497 reactions. One may suspect that maximum error of this 81 -species mechanism will be larger. In fact, the maximum absolute relative error on ignition delay time is $9.13 \%$, which meets our requirement on skeletal mechanism. It is worth noting that the skeletal mechanism with r-DRGEP contains 85 species, while the mechanism from intersection of all the six skeletal mechanism contains 81 species. This indicates that $r$-DRGEP is rather effective in removing unimportant species for this mechanism. Detailed information about the seven mechanisms is provided in Table S1 of Supporting Information. It should be noted that performance of mechanism reduction methods depends on the detailed mechanism. The fact that r-DRGEP is better than the other methods in reduction of the AramcoMech 1.3 mechanism does not necessarily mean that it will be as effective in removing redundant species for other mechanisms.

Maximum relative errors in ignition delay times with the seven skeletal mechanisms over a wide range of equivalence ratios $(0.5-$ $2.0)$, initial temperatures $(800-1600 \mathrm{~K})$, pressures $\left(1.01 \times 10^{5}-\right.$ $3.04 \times 10^{6} \mathrm{~Pa}$ ) for pure $\mathrm{H}_{2}, \mathrm{CO}, \mathrm{CH}_{4}, \mathrm{CH}_{2} \mathrm{O}, \mathrm{CH}_{3} \mathrm{OH}, \mathrm{C}_{2} \mathrm{H}_{2}, \mathrm{C}_{2} \mathrm{H}_{4}$, $\mathrm{C}_{2} \mathrm{H}_{6}, \mathrm{C}_{2} \mathrm{H}_{3} \mathrm{OH}$, and $\mathrm{C}_{2} \mathrm{H}_{5} \mathrm{OH}$ are illustrated respectively in Table 1. One can see from this table that error of the ignition delay time with these skeletal mechanisms is less than $0.43 \%$ for $\mathrm{CH}_{4}$ and $\mathrm{CH}_{3} \mathrm{OH}$, and within $3.0 \%$ for $\mathrm{CH}_{2} \mathrm{O}, \mathrm{C}_{2} \mathrm{H}_{5} \mathrm{OH}, \mathrm{CH}_{3} \mathrm{CHO}$, within $10.0 \%$ for $\mathrm{C}_{2} \mathrm{H}_{2}, \mathrm{C}_{2} \mathrm{H}_{4}$, and $\mathrm{C}_{2} \mathrm{H}_{6}$. In addition, error in the ignition delay time with the skeletal mechanism from intersection approach is similar to those of the other skeletal mechanisms, although the number of species is reduced to some extent. In fact, error in ignition delay time of $\mathrm{C}_{2} \mathrm{H}_{4}$ with the 81-species mechanism is even smaller than that with the skeletal mechanisms from rDRGEP and PFAEP. This demonstrates reliability of the intersection approach in achieving skeletal mechanisms. It can also be seen from this table that error in ignition delay time with the skeletal mechanism increases with size of the fuel. This may be related to the fact that reaction paths for combustion of large fuels are more complicated. Furthermore, error of ignition delay times for $\mathrm{CO}$ and $\mathrm{H}_{2}$ is less than $0.01 \%$ and it is much smaller than those of the other fuels. This is understandable since combustion pro- 
Table 1 Maximum error of predicted ignition delay times of skeletal mechanisms for targeted fuels with equivalence ratios of $0.5-2.0$, pressures of $1.01 \times 10^{5}-3.04 \times 10^{6} \mathrm{~Pa}$, and temperatures of $800-1800 \mathrm{~K}$

\begin{tabular}{|c|c|c|c|c|c|c|c|}
\hline & DRG & DRGEP & r-DRG & r-DRGEP & PFA & PFAEP & Intersection \\
\hline $\mathrm{H}_{2}$ & $0.0038 \%$ & $0.0029 \%$ & $0.0052 \%$ & $0.0051 \%$ & $0.0032 \%$ & $0.0033 \%$ & $0.0076 \%$ \\
\hline $\mathrm{CO}$ & $0.0032 \%$ & $0.0032 \%$ & $0.0067 \%$ & $0.0046 \%$ & $0.0090 \%$ & $0.0075 \%$ & $0.0055 \%$ \\
\hline $\mathrm{CH}_{4}$ & $0.2219 \%$ & $0.0460 \%$ & $0.2365 \%$ & $0.4295 \%$ & $0.2350 \%$ & $0.2096 \%$ & $0.4295 \%$ \\
\hline $\mathrm{CH}_{2} \mathrm{O}$ & $1.6166 \%$ & $0.0027 \%$ & $1.6166 \%$ & $0.2678 \%$ & $1.6166 \%$ & $0.0027 \%$ & $1.6166 \%$ \\
\hline $\mathrm{CH}_{3} \mathrm{OH}$ & $0.0212 \%$ & $0.0005 \%$ & $0.1002 \%$ & $0.0997 \%$ & $0.0998 \%$ & $0.0033 \%$ & $0.0998 \%$ \\
\hline $\mathrm{C}_{2} \mathrm{H}_{2}$ & $9.3969 \%$ & $5.0850 \%$ & $5.0387 \%$ & $8.3053 \%$ & $9.3671 \%$ & $2.2564 \%$ & $9.1305 \%$ \\
\hline $\mathrm{C}_{2} \mathrm{H}_{4}$ & $6.2570 \%$ & $6.7866 \%$ & $6.5455 \%$ & $8.0937 \%$ & $6.1916 \%$ & $8.0708 \%$ & $6.5872 \%$ \\
\hline $\mathrm{C}_{2} \mathrm{H}_{6}$ & $0.5146 \%$ & $0.5253 \%$ & $2.6561 \%$ & $5.2594 \%$ & $2.7874 \%$ & $0.5340 \%$ & $5.2146 \%$ \\
\hline $\mathrm{C}_{2} \mathrm{H}_{5} \mathrm{OH}$ & $0.3668 \%$ & $0.3901 \%$ & $1.3453 \%$ & $2.0473 \%$ & $1.3936 \%$ & $0.3658 \%$ & $2.1814 \%$ \\
\hline $\mathrm{CH}_{3} \mathrm{CHO}$ & $2.7364 \%$ & $1.4818 \%$ & $2.7386 \%$ & $2.8297 \%$ & $2.7391 \%$ & $2.7794 \%$ & $2.9696 \%$ \\
\hline Number of species/reactions & $171 / 1258$ & $119 / 836$ & $131 / 928$ & $85 / 509$ & $176 / 1295$ & $105 / 722$ & $81 / 497$ \\
\hline
\end{tabular}

cesses of $\mathrm{CO}$ and $\mathrm{H}_{2}$ are basis of combustion of hydrocarbon and oxygenated fuels. Describing reaction process of $\mathrm{CO}$ and $\mathrm{H}_{2}$ with high accuracy is a prerequisite for a mechanism to predict combustion properties of hydrocarbon and oxygenated fuels reliably.

The 81-species skeletal mechanism is proposed to describe the hydrocarbon and oxygenated hydrocarbon oxidation of $\mathrm{C}_{1}-\mathrm{C}_{2}$ species. However, 23 species larger than $\mathrm{C}_{2}$ still exist in the skeletal mechanism. To describe combustion properties of $\mathrm{C}_{1}-\mathrm{C}_{2}$ species accurately, it is necessary to include some $\mathrm{C}_{3}$ and $\mathrm{C}_{4}$ chemistry particularly under fuel rich conditions. It is demonstrated by Metcalfe et al. ${ }^{1}$ that $\mathrm{C}_{3} \mathrm{H}_{8}, \mathrm{C}_{4} \mathrm{H}_{2}$, and $\mathrm{C}_{4} \mathrm{H}_{10}$ are rather important in combustion process of some $\mathrm{C}_{1}-\mathrm{C}_{2}$ species and these species are retained in the 81 -species skeletal mechanism. In the following, we will validate the 81 -species skeletal mechanism.

\subsection{Ignition of two-component mixtures}

The skeletal mechanism is shown to afford ignition delay times for single-component fuels that agree well with those of the detailed mechanism. However, practical fuels are multi-component mixtures in most cases. To further demonstrate reliability of the achieved skeletal mechanism, auto-ignition processes for twocomponent mixed fuels are also simulated. In this work, ignition delay times of eight two-component of mixtures are studies with the detailed and the skeletal mechanisms. These simulations are carried out at equivalence ratio of 1.0, initial temperatures from 800 to $1800 \mathrm{~K}$, and constant pressures of $1.01 \times 10^{5}$ and $1.01 \times 10^{6}$ $\mathrm{Pa}$. Auto-ignition delay times for mixtures with equal proportion are illustrated in Fig. 1 and those for $\mathrm{CH}_{4}-\mathrm{C}_{2} \mathrm{H}_{4}$ and $\mathrm{CH}_{2} \mathrm{O}-\mathrm{C}_{2} \mathrm{H}_{5} \mathrm{OH}$ mixture with different proportions are shown in Fig.2. We can see from Figs. 1 and 2 that the 81 -species skeletal mechanism reproduces results of the detailed mechanism satisfactorily. Considering the fact that the skeletal mechanism is able to predict ignition delay times of single component fuels, the skeletal mechanism should provide reliable prediction on ignition delay times for the other mixtures compared with the detailed mechanism.

\subsection{Temperature profile}

From the above results and discussions, the 81 -species skeletal mechanism reproduces ignition delay time of single and twocomponent fuels of the detailed mechanism satisfactorily. In order to further illustrate reliability of the achieved skeletal mechanism, other combustion characteristics of $\mathrm{C}_{1}-\mathrm{C}_{2}$ species are further verified in this section.

Temperature profile in constant pressure auto-ignition process with the detailed and the 81-species skeletal mechanisms is illustrated in Fig.3. It can be seen that the skeletal mechanism reproduces temperature change of the detailed mechanism rather well. Furthermore, the results indicate that adiabatic flame
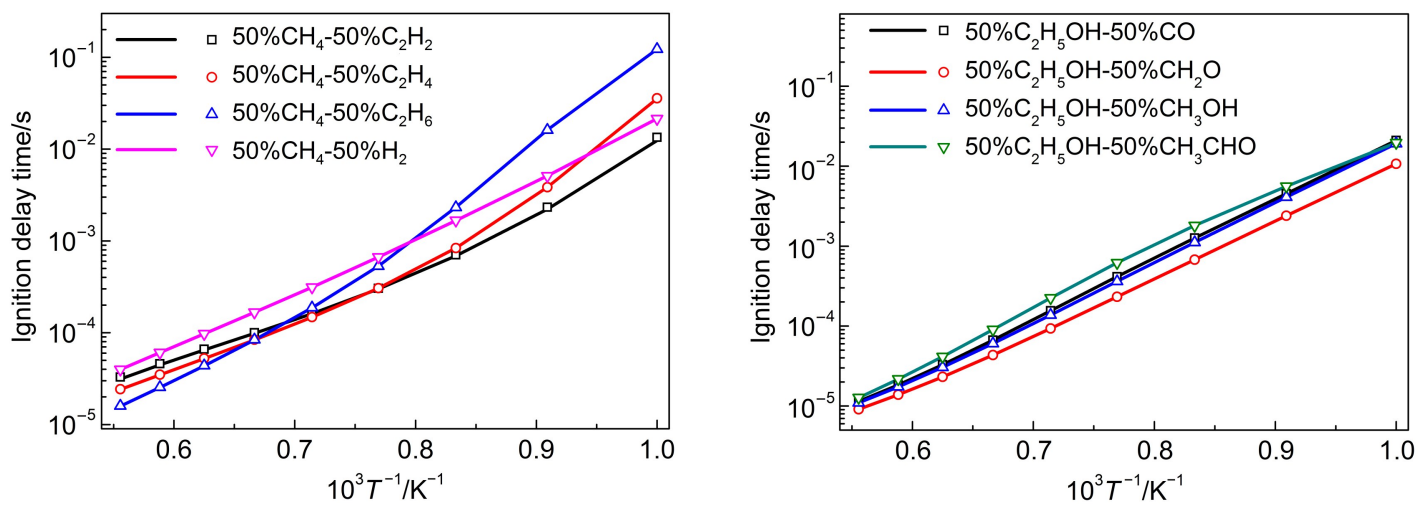

Fig.1 Ignition delay time of two-components mixtures using the 81-species skeletal mechanisms (symbols) and detailed mechanism (lines) with equivalence ratio of 1.0 , pressure of $1.01 \times 10^{5} \mathrm{~Pa}$, and initial temperatures of $1000-1800 \mathrm{~K}$ 

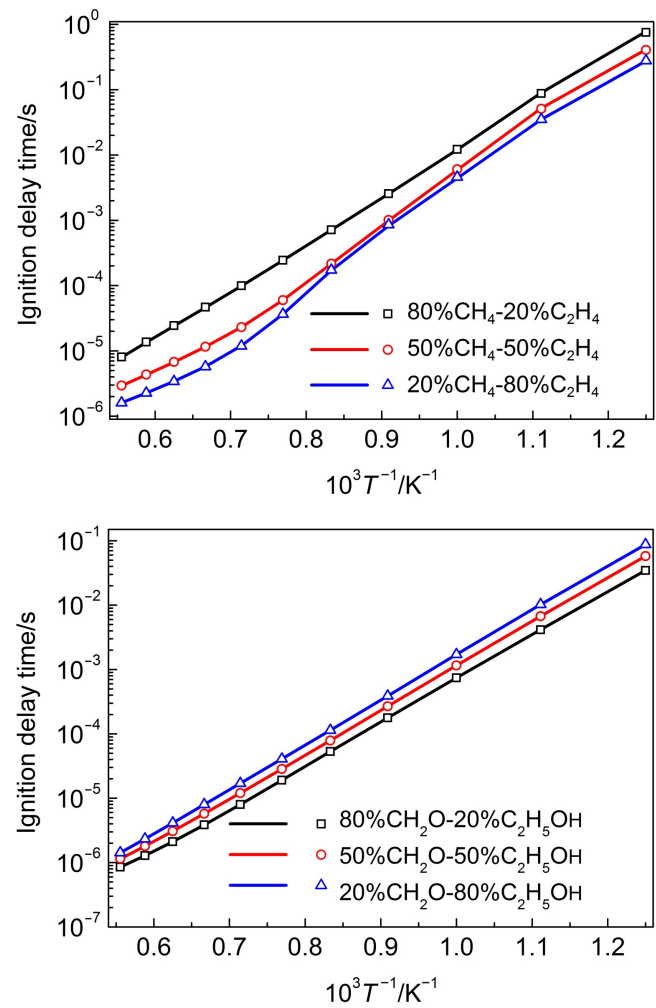

Fig.2 Ignition delay time for mixtures of different proportions using 81-species skeletal mechanisms (symbols) and detailed mechanism (lines) with equivalence ratio of 1.0 , pressure of

$1.01 \times 10^{6} \mathrm{~Pa}$, and initial temperatures of $800-1800 \mathrm{~K}$ color online

temperatures of these hydrocarbon fuels increase with mass fraction of carbon under the same initial conditions, i.e., $T\left(\mathrm{C}_{2} \mathrm{H}_{2}\right)>$ $T\left(\mathrm{C}_{2} \mathrm{H}_{4}\right)>T\left(\mathrm{C}_{2} \mathrm{H}_{6}\right)>T\left(\mathrm{CH}_{4}\right)$.

\subsection{Mole fraction profile}

Major species profiles in oxidation of target fuels in a perfectly stirred reactor $(\mathrm{PSR})^{40}$ are calculated based on the detailed and the 81-species skeletal mechanisms respectively. Fig.4 shows mole fractions of selected important species with respect to temperature in PSR under an equivalence ratio of 1.0 , pressure of $5.05 \times 10^{5}$ $\mathrm{Pa}$, and residence time of $0.07 \mathrm{~s}$. It can be seen from this figure that concentrations of these species with the skeletal mechanism agree very well with those of the detailed mechanism. This figure will also provide information on combustion characters of these fuels at different temperatures. Oxygenated $\mathrm{C}_{1}-\mathrm{C}_{2}$ fuels will be oxidized already at $800 \mathrm{~K}$, while the hydrocarbon fuels begin to react significantly at a higher temperature. This is consistent with the fact that ignition delay times of oxygenated fuels of $\mathrm{C}_{1}-\mathrm{C}_{2}$ are shorter than hydrocarbon fuels of $\mathrm{C}_{1}-\mathrm{C}_{2}$.

\subsection{Flame profile}

To validate performance of the skeletal mechanism in simulation flames where transport properties play a role, simulations on laminar flame are carried out using the skeletal and detailed mechanisms. In development of the AramcoMech 1.3 mechanism, laminar flame speeds for $\mathrm{CH}_{4}, \mathrm{C}_{2} \mathrm{H}_{4}, \mathrm{C}_{2} \mathrm{H}_{6}, \mathrm{CH}_{3} \mathrm{OH}, \mathrm{C}_{2} \mathrm{H}_{5} \mathrm{OH}$ as
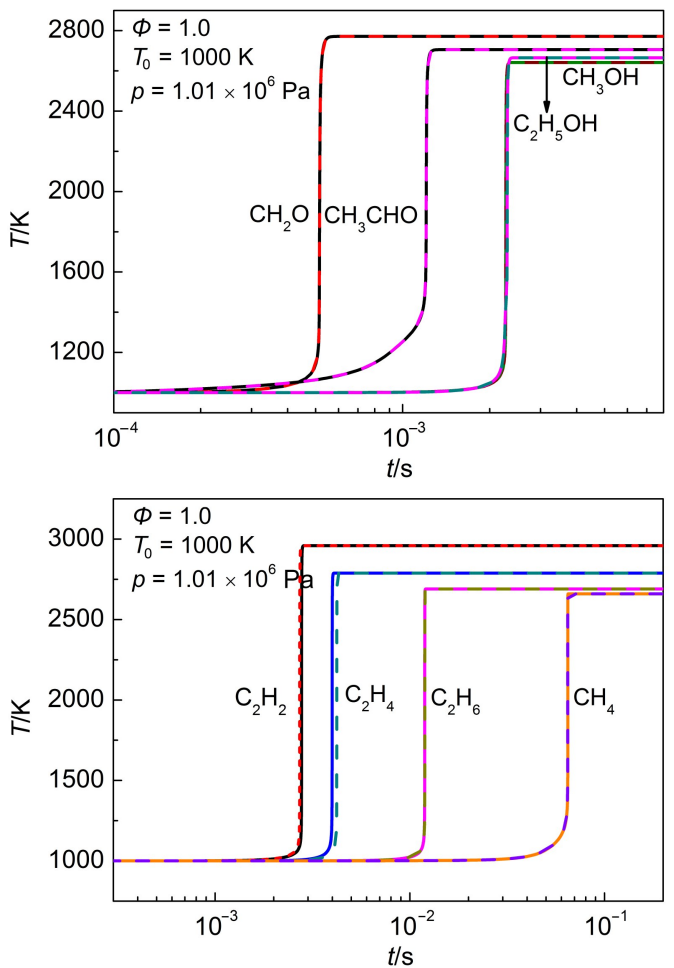

Fig.3 Temperature profiles in a closed constant-pressure reactor using 81-species skeletal mechanism (dash line) and detailed mechanism (solid line) $\Phi$ : equivalence ratio

well as $\mathrm{CH}_{4}-\mathrm{C}_{2} \mathrm{H}_{6}$ mixture are validated against experimental data. Laminar flame speed for these fuels at different equivalence ratios for fuels/air flames calculated with the PREMIX program ${ }^{41}$ at various temperatures and pressures using the detailed and 81species skeletal mechanisms are shown in Fig.5. Our results demonstrate that the skeletal mechanism can reproduce laminar flame speeds of the detailed mechanism accurately. It should be noted that computational effort in simulation of laminar flames speeds depends critically on number of species in the mechanism and it is reduced to a large extent with the skeletal mechanism.

It is clear that the 81 -species mechanism is about 3 times smaller than the detailed mechanism. The computation time of 0 $\mathrm{D}$ or 1-D simulations is about a quadratic function of the number of species in a kinetics mechanism. ${ }^{42}$ In our calculations, computation time in simulation of ignition delay time or laminar flames speeds with detailed mechanism is about 10 times that of simulations using the 81 -species mechanism.

\section{Expanded verification and analysis}

Reaction path analysis is an important tool to help understanding main reaction processes in combustion of fuels and to facilitate mechanism generation. Moreover, reaction path analysis can also be adopted to evaluate quality of the achieved skeletal mechanisms and verify the rationality and accuracy of skeletal mechanism. Reaction paths for combustion of $\mathrm{CH}_{4}, \mathrm{C}_{2} \mathrm{H}_{2}, \mathrm{C}_{2} \mathrm{H}_{4}$, and $\mathrm{C}_{2} \mathrm{H}_{6}$ had been discussed previously ${ }^{3,7,11}$ and we focus on 

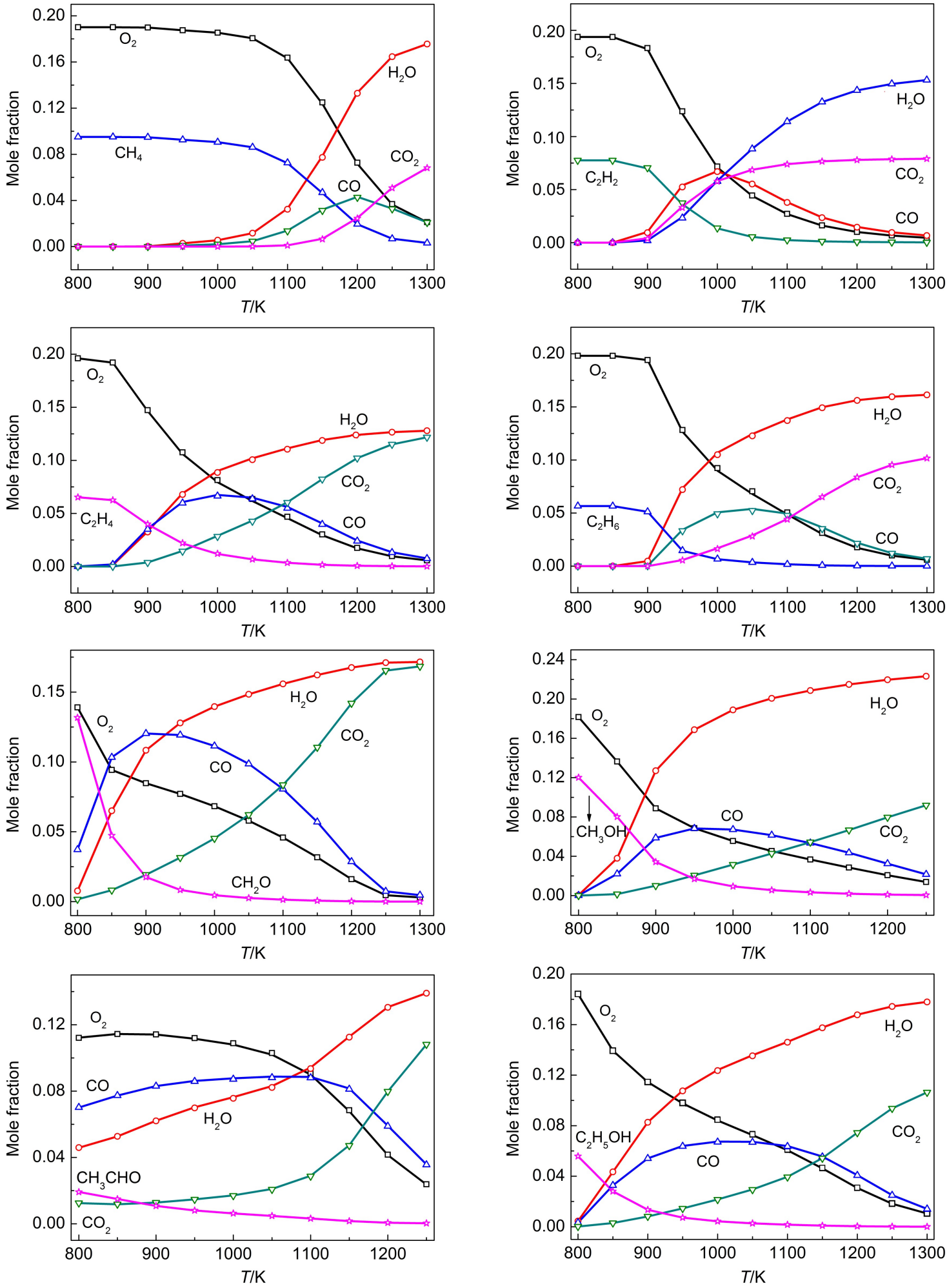

Fig.4 Mole fractions of some important species in PSR using 81-species skeletal mechanism (symbol) and detailed mechanism (solid line) for the targeted fuels with equivalence ratio of 1.0 , pressure of $5.05 \times 10^{5} \mathrm{~Pa}$, and temperatures of $800-1300 \mathrm{~K}$

combustion processes of pure $\mathrm{CH}_{2} \mathrm{O}, \mathrm{CH}_{3} \mathrm{OH}, \mathrm{CH}_{3} \mathrm{CHO}$, and $\mathrm{C}_{2} \mathrm{H}_{5} \mathrm{OH}$ based on time-integrated element flux analysis respectively. Their reaction paths in a constant-pressure auto-ignition process with the skeletal mechanism and the detailed mechanism are clarified under pressure of $1.01 \times 10^{5} \mathrm{~Pa}$, equivalent ratio of
1.0 , temperatures of 900 and $1400 \mathrm{~K}$, respectively. These results are illustrated in Figs.6-9. The upper and lower values in these figures are percentages of conversions at initial temperatures of 900 and $1400 \mathrm{~K}$, respectively. Data in parentheses are results with the skeletal mechanism. One can see from Figs.6-9 that reaction 

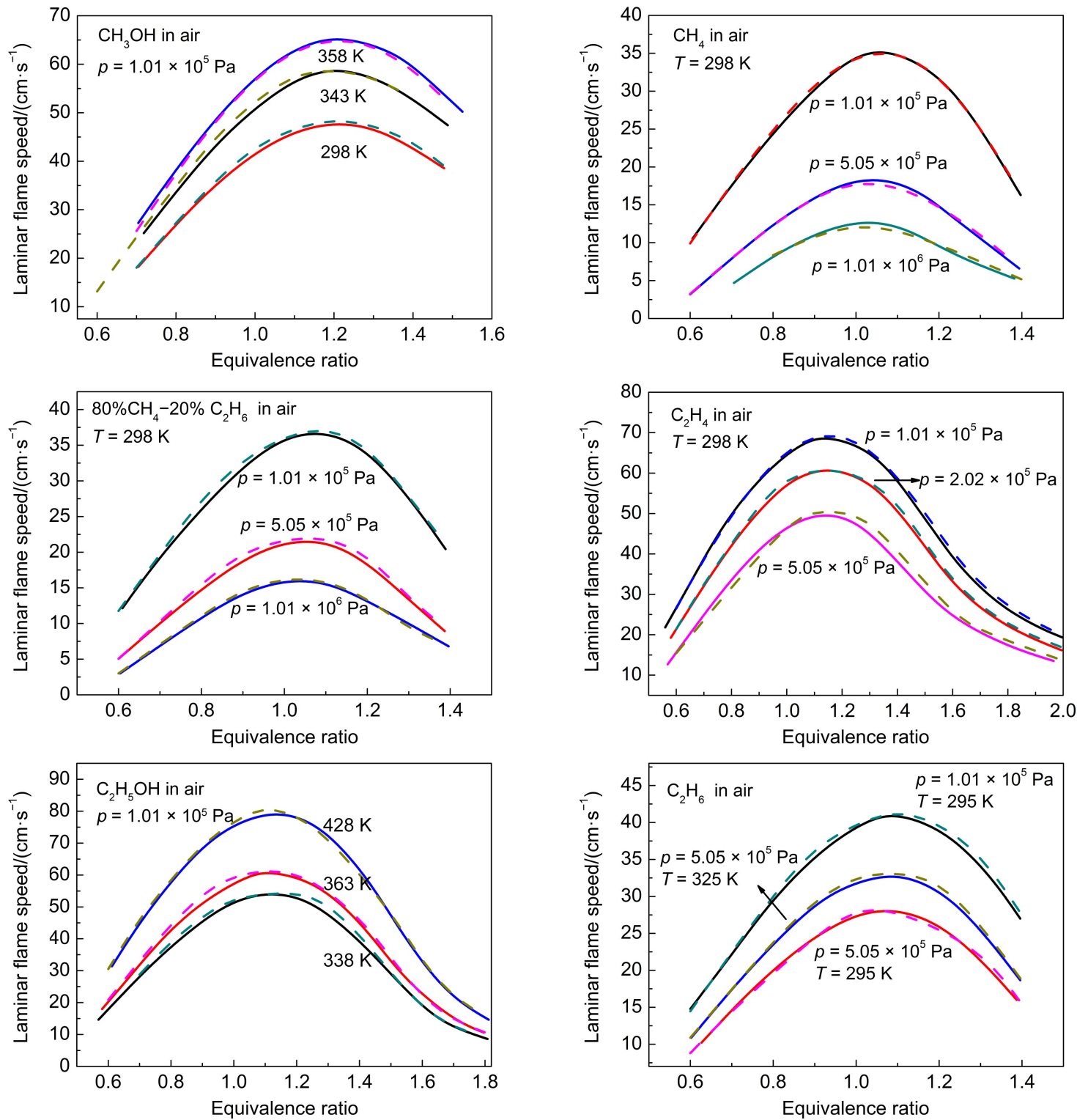

Fig.5 Laminar flame speeds in air for the targeted fuels using 81-species skeletal (dash lines) and detailed (solid lines) mechanisms

paths with the skeletal mechanism for these fuels are in excellent agreement with those of the detailed mechanism. Similar situation also occurs for $\mathrm{CH}_{4}, \mathrm{C}_{2} \mathrm{H}_{2}, \mathrm{C}_{2} \mathrm{H}_{4}$, and $\mathrm{C}_{2} \mathrm{H}_{6}$. These results indicate that major reaction paths of these ignition processes are captured by the skeletal mechanism, and important species and reactions are retained in the skeletal mechanism. This shows that reliability of the 81-species mechanism stems from its retaining all the important reaction paths in combustion of these fuels.

According to our results, $\mathrm{CH}_{2} \mathrm{O}$ is consumed mainly through $\mathrm{H}$ abstraction reactions by $\mathrm{OH}, \mathrm{H}, \mathrm{HO}_{2}$, and $\mathrm{O}$ radicals to produce HCO. A small amount of $\mathrm{CH}_{2} \mathrm{O}$ will react with $\mathrm{OH}$ radical and generate $\mathrm{HOCH}_{2} \mathrm{O}$ by the addition reaction: $\mathrm{CH}_{2} \mathrm{O}+\mathrm{OH}=$ $\mathrm{HOCH}_{2} \mathrm{O}$ at $900 \mathrm{~K}$. This addition reaction is an exothermic barrierless reaction and it is thus unimportant at high temperature. There are two reaction channels for HCO to produce CO: $65.3 \%$ of $\mathrm{HCO}$ will undergo reaction $\mathrm{HCO}+\mathrm{O}_{2}=\mathrm{CO}+\mathrm{HO}_{2}$ and $29.8 \%$ of $\mathrm{HCO}$ will form $\mathrm{CO}$ through decomposition: $\mathrm{HCO}+\mathrm{M}=\mathrm{H}+$ $\mathrm{CO}+\mathrm{M}$ at $900 \mathrm{~K}$, while they are $40.7 \%$ and $53.4 \%$, respectively at $1400 \mathrm{~K}$. It is understandable that decomposition path of HCO to form $\mathrm{CO}$ will be more pronounced at higher temperature. $\mathrm{CO}+$ $\mathrm{OH}=\mathrm{CO}_{2}+\mathrm{H}$ is the main consumption route of $\mathrm{CO}$, which is one of the most important exothermic reactions in combustion process. It is worth noting that a small amount of $\mathrm{CO}$ will react with $\mathrm{H}_{2} \mathrm{O}$ to form $\mathrm{HOCHO}$ and this reaction path becomes more important at high temperature. $\mathrm{HOCHO}$ will react further with $\mathrm{OH}$ or $\mathrm{H}$ radicals to form $\mathrm{CO}_{2}$.

$\mathrm{CH}_{3} \mathrm{OH}$ is mainly consumed through $\mathrm{H}$-abstraction reactions with $\mathrm{OH}, \mathrm{HO}_{2}, \mathrm{H}$, and $\mathrm{O}$ radicals and dominant product of these reactions is $\mathrm{CH}_{2} \mathrm{OH}$ with $\mathrm{CH}_{3} \mathrm{O}$ as the minor product. Bond dissociation energies of $\mathrm{C}-\mathrm{H}$ and $\mathrm{O}-\mathrm{H}$ in $\mathrm{CH}_{3} \mathrm{OH}$ are $4.02 \times 10^{5}$ and $4.36 \times 10^{5} \mathrm{~J} \cdot \mathrm{mol}^{-1}$, respectively ${ }^{43}$. This explains that hydrogen atoms connected with the carbon atom are extracted more easily 


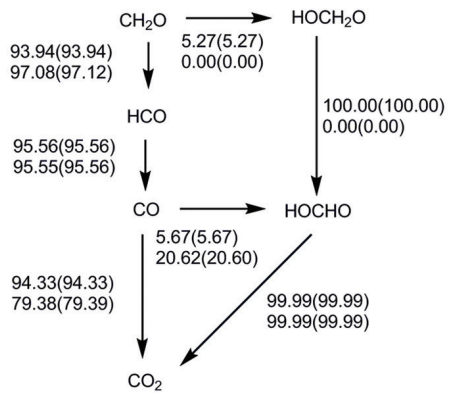

Fig.6 Time-integrated element flux analysis of formaldehyde $\left(\mathrm{CH}_{2} \mathrm{O}\right)$ in constant pressure auto-ignition processes

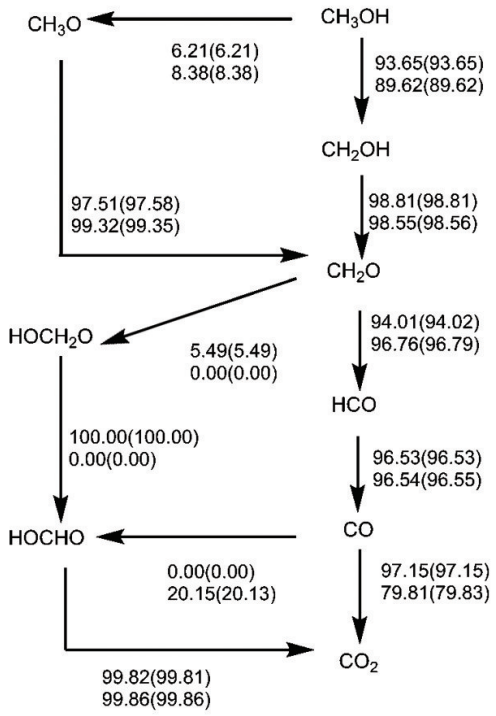

Fig.7 Time-integrated element flux analysis of methanol

$\left(\mathrm{CH}_{3} \mathrm{OH}\right)$ in constant pressure auto-ignition processes

than that within hydroxyl in $\mathrm{CH}_{3} \mathrm{OH}$. $\mathrm{CH}_{2} \mathrm{OH}$ mainly undergoes $\mathrm{H}$-abstraction reaction with $\mathrm{O}_{2}$ to form $\mathrm{CH}_{2} \mathrm{O}: \mathrm{CH}_{2} \mathrm{OH}+\mathrm{O}_{2}=$ $\mathrm{CH}_{2} \mathrm{O}+\mathrm{HO}_{2}$. On the other hand, $\mathrm{CH}_{2} \mathrm{O}$ will also be produced from $\mathrm{CH}_{3} \mathrm{O}$ either through decomposition: $\mathrm{CH}_{3} \mathrm{O}(+\mathrm{M})=\mathrm{CH}_{2} \mathrm{O}+\mathrm{H}(+\mathrm{M})$ or through $\mathrm{H}$-abstraction reaction with $\mathrm{O}_{2}: \mathrm{CH}_{3} \mathrm{O}+\mathrm{O}_{2}=\mathrm{CH}_{2} \mathrm{O}+$ $\mathrm{HO}_{2}$.

Reaction path for $\mathrm{CH}_{3} \mathrm{CHO}$ is much more complicated than that of $\mathrm{CH}_{2} \mathrm{O}$ and $\mathrm{CH}_{3} \mathrm{OH}$ and difference in reaction paths under low-

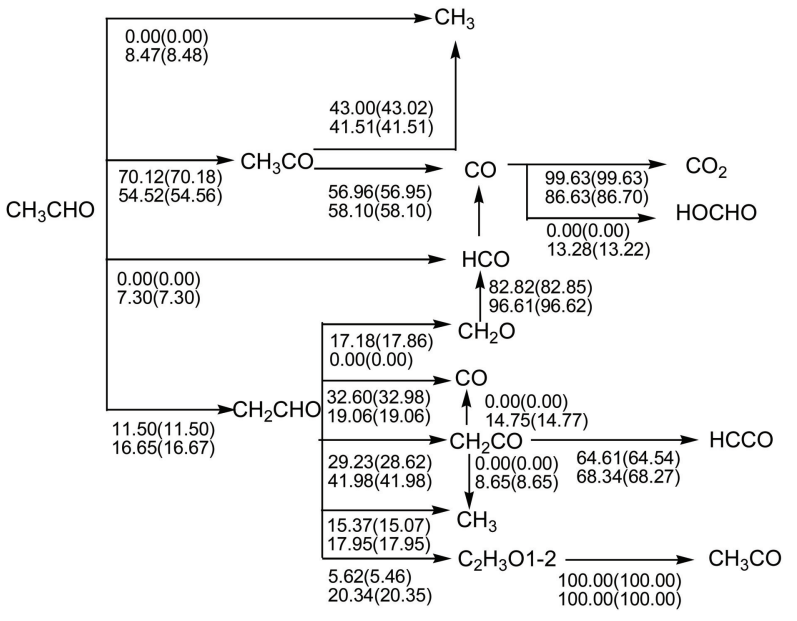

Fig.8 Time-integrated element flux analysis of aldehyde $\left(\mathrm{CH}_{3} \mathrm{CHO}\right)$ in constant pressure auto-ignition processes

and high-temperature is also more pronounced. Main consumption paths of $\mathrm{CH}_{3} \mathrm{CHO}$ are still $\mathrm{H}$-abstraction reactions by $\mathrm{OH}, \mathrm{H}, \mathrm{CH}_{3}$, and $\mathrm{HO}_{2}$ radicals at both low- and high-temperature. Product of these $\mathrm{H}$-abstractions is mainly $\mathrm{CH}_{3} \mathrm{CO}$ and a small amount of $\mathrm{CH}_{2} \mathrm{CHO}$ will also be produced in these reactions. In addition, a few $\mathrm{CH}_{3}$ and $\mathrm{HCO}$ will also be produced via the following decomposition reaction at high-temperature:

$\mathrm{CH}_{3} \mathrm{CHO}(+\mathrm{M})=\mathrm{CH}_{3}+\mathrm{HCO}(+\mathrm{M})$

$\mathrm{CH}_{3} \mathrm{CO}$ undergoes a simple bond breaking reaction to form $\mathrm{CH}_{3}$ and $\mathrm{CO}$ :

$\mathrm{CH}_{3} \mathrm{CO}(+\mathrm{M})=\mathrm{CH}_{3}+\mathrm{CO}(+\mathrm{M})$

On the other hand, reaction paths for consumption of $\mathrm{CH}_{2} \mathrm{CHO}$ are much more involved. $\mathrm{CH}_{2} \mathrm{CHO}$ can either react with $\mathrm{O}_{2}$ to form $\mathrm{CO}, \mathrm{OH}$, and $\mathrm{CH}_{2} \mathrm{O}$, directly decompose into $\mathrm{CH}_{3}$ and $\mathrm{CO}$ or $\mathrm{CH}_{2} \mathrm{CO}$ and $\mathrm{H}$, or isomerize to oxirane radical. Decomposition of $\mathrm{CH}_{2} \mathrm{CHO}$ is the most important reaction path at both high and low temperatures. $\mathrm{CH}_{2} \mathrm{CO}$ will react with $\mathrm{H}$ or $\mathrm{OH}$ radicals to form $\mathrm{CO}, \mathrm{CH}_{3}$, and $\mathrm{HCCO}$, while $\mathrm{CO}, \mathrm{CO}_{2}$, and $\mathrm{CH}_{2}(\mathrm{~S})$ will be produced from $\mathrm{HCCO}$.

Main consumption reaction paths of $\mathrm{C}_{2} \mathrm{H}_{5} \mathrm{OH}$ are $\mathrm{H}$-abstraction reactions by $\mathrm{OH}, \mathrm{H}, \mathrm{CH}_{3}, \mathrm{HO}_{2}$ radicals. Products of these $\mathrm{H}$ abstraction reactions are $\mathrm{PC}_{2} \mathrm{H}_{4} \mathrm{OH}$ and $\mathrm{SC}_{2} \mathrm{H}_{4} \mathrm{OH}$, which correspond to primary and secondary carbon radicals, respectively. As

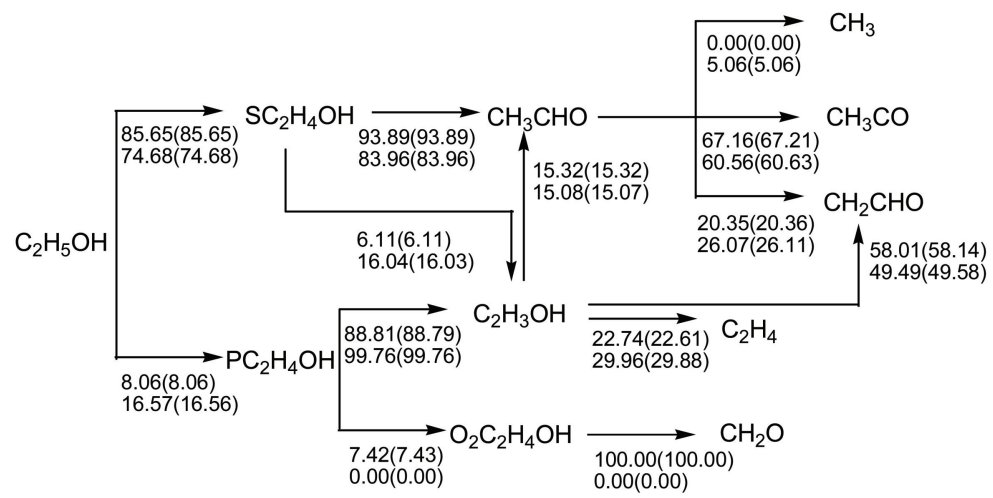

Fig.9 Time-integrated element flux analysis of alcohol $\left(\mathrm{C}_{2} \mathrm{H}_{5} \mathrm{OH}\right)$ in constant pressure auto-ignition processes 
one would expect, the main product of these $\mathrm{H}$-abstraction reactions is $\mathrm{SC}_{2} \mathrm{H}_{4} \mathrm{OH}$. $\mathrm{SC}_{2} \mathrm{H}_{4} \mathrm{OH}$ mainly reacts with $\mathrm{O}_{2}$ to generate $\mathrm{CH}_{3} \mathrm{CHO}$ and $\mathrm{C}_{2} \mathrm{H}_{3} \mathrm{OH}$ :

$$
\mathrm{SC}_{2} \mathrm{H}_{4} \mathrm{OH}+\mathrm{O}_{2}=\mathrm{CH}_{3} \mathrm{CHO}+\mathrm{HO}_{2}
$$$$
\mathrm{SC}_{2} \mathrm{H}_{4} \mathrm{OH}+\mathrm{O}_{2}=\mathrm{C}_{2} \mathrm{H}_{3} \mathrm{OH}+\mathrm{HO}_{2}
$$

On the other hand, consumption of $\mathrm{PC}_{2} \mathrm{H}_{4} \mathrm{OH}$ is mainly through the following reactions:

$$
\mathrm{PC}_{2} \mathrm{H}_{4} \mathrm{OH}=\mathrm{C}_{2} \mathrm{H}_{3} \mathrm{OH}+\mathrm{H}
$$$$
\mathrm{PC}_{2} \mathrm{H}_{4} \mathrm{OH}+\mathrm{O}_{2}=\mathrm{O}_{2} \mathrm{C}_{2} \mathrm{H}_{4} \mathrm{OH}
$$

to form $\mathrm{C}_{2} \mathrm{H}_{3} \mathrm{OH}$ and $\mathrm{O}_{2} \mathrm{C}_{2} \mathrm{H}_{4} \mathrm{OH}$. The reaction channel $\mathrm{PC}_{2} \mathrm{H}_{4} \mathrm{OH}+$ $\mathrm{O}_{2}=\mathrm{O}_{2} \mathrm{C}_{2} \mathrm{H}_{4} \mathrm{OH}$ becomes unimportant at high temperature. $\mathrm{C}_{2} \mathrm{H}_{3} \mathrm{OH}$ will react with $\mathrm{H}$ and $\mathrm{OH}$ to form $\mathrm{CH}_{2} \mathrm{CHO}$ and $\mathrm{C}_{2} \mathrm{H}_{4}$ : $\mathrm{C}_{2} \mathrm{H}_{3} \mathrm{OH}+\mathrm{OH}=\mathrm{CH}_{2} \mathrm{CHO}+\mathrm{H}_{2} \mathrm{O}, \mathrm{C}_{2} \mathrm{H}_{3} \mathrm{OH}+\mathrm{H}=\mathrm{C}_{2} \mathrm{H}_{4}+\mathrm{OH}$. Another important reaction channel of $\mathrm{C}_{2} \mathrm{H}_{3} \mathrm{OH}$ is to form $\mathrm{CH}_{3} \mathrm{CHO}$ through isomerization: $\mathrm{C}_{2} \mathrm{H}_{3} \mathrm{OH}=\mathrm{CH}_{3} \mathrm{CHO} . \mathrm{O}_{2} \mathrm{C}_{2} \mathrm{H}_{4} \mathrm{OH}$ will directly decompose into $\mathrm{CH}_{2} \mathrm{O}$ and $\mathrm{OH}$.

One can see from these results that $\mathrm{CH}_{2} \mathrm{O}$ exists in combustion process of $\mathrm{CH}_{3} \mathrm{OH}, \mathrm{CH}_{3} \mathrm{CHO}$, and $\mathrm{C}_{2} \mathrm{H}_{5} \mathrm{OH}$, and $\mathrm{CH}_{3} \mathrm{CHO}$ is a main intermediate species in reaction path of $\mathrm{C}_{2} \mathrm{H}_{5} \mathrm{OH}$. Similarly, these $\mathrm{C}_{1}-\mathrm{C}_{2}$ fuels will also be important intermediates in combustion of large hydrocarbon and oxygenated fuels. Time-integrated element flux analysis show that the 81-species skeletal mechanism captured major combustion paths for $\mathrm{C}_{1}-\mathrm{C}_{2}$ species and chemical hierarchical structure of detailed mechanism. Understanding the combustion process of these oxygenated fuels can be facilitated with the skeletal mechanism.

\section{Conclusions}

The AramcoMech 1.3 mechanism for describing oxidation of hydrocarbon and oxygenated $\mathrm{C}_{1}-\mathrm{C}_{2}$ species over a wide range of conditions is reduced with DRG, r-DRG, PFA, DRGEP, r-DRGEP, and PFAEP. Performance of mechanism reduction methods is closely related to the detailed mechanism and it is difficult to tell in advance which mechanism reduction method will be the most effective. According to our results, error propagation methods can remove unimportant species in this mechanism effectively. Compared with the other mechanism reduction methods, rDRGEP can provide a skeletal mechanism with less species when the maximum error in ignition delay time with the skeletal mechanisms is less than $10 \%$. On the other hand, by taking intersection of the six skeletal mechanisms obtained from these mechanism reduction methods, a skeletal mechanism with 81 species is achieved. The maximum error of this skeletal mechanism from intersection approach on ignition delay time of each fuel is $9.13 \%$ and it is still less than $10 \%$. This shows that some redundant species can be removed further based on intersection of a set of skeletal mechanisms without increasing simulation error significantly.

Besides single-component fuels, ignition for some two-component mixtures are also simulated and the skeletal mechanism can reproduce results of the detailed mechanism accurately. Ignition delay times of a mixture usually lie between those of the corresponding single component fuel. Furthermore, the skeletal mechanism has also been validated against the detailed one over many other combustion characters of the involved fuels such as temperature profiles in constant pressure auto-ignition processes, major species profiles in PSR, laminar flame speeds. All these results show that combustion properties of these $C_{1}-C_{2}$ fuels with the detailed mechanism are reproduced accurately with the skeletal mechanism. Time- integrated element flux analysis is carried out to clarify combustion process of $\mathrm{C}_{1}-\mathrm{C}_{2}$ fuels with the detailed mechanism and the 81 -species skeletal mechanism. Reaction paths with the skeletal mechanism for these fuels closely resemble those of the detailed mechanism. This indicates that all the important reaction paths are retained in the 81- species mechanism. The 81 -species skeletal mechanism can be adopted as core mechanism for developing mechanisms of other large hydrocarbon or oxygenated fuels.

Acknowledgments: We acknowledge National Supercomputing Center in Shenzhen for providing the computational resources and software.

Supporting Information: Retained species in the corresponding skeletal mechanisms with the predicted errors of ignition delay time controlled within $10 \%$ have been included. This information is available free of charge via the internet at http://www. whxb.pku.edu.cn.

\section{References}

(1) Metcalfe, W. K.; Burke, S. M.; Ahmed, S. S.; Curran, H. J. Int. J. Chem. Kinet. 2013, 45, 638. doi: 10.1002/kin.20802

(2) Simmie, J. M. Prog. Energy Combust. Sci. 2003, 29, 599. doi: 10.1016/S0360-1285(03)00060-1

(3) Wang, Q. D. Energy Fuels 2013, 27, 4021. doi: 10.1021/ ef 4007774

(4) Guo, J. J.; Hua, X. X.; Wang, F.; Tan, N. X.; Li, X. Y. Acta Phys. -Chim. Sin. 2014, 30, 1027. [郭俊江, 华晓符, 王 繁, 谈 宁馨, 李象远. 物理化学学报, 2014, 30, 1027.] doi: 10.3866/ PKU.WHXB201404031

(5) You, X. Q.; Egolfopoulos, F. N.; Wang, H. Proc. Combust. Inst. 2009, 32, 403. doi: 10.1016/j.proci.2008.06.041

(6) Dagaut, P.; Boettner, J. C.; Cathonnet, M. Combust Sci. Technol. 1991, 77, 127. doi: 10.1080/00102209108951723

(7) Morio, H.; Naoki, M.; Nick, M.; Pitz, W.; Westbrook, C. Proc. Combust. Inst. 1998, 27, 389. doi: 10.1016/S0082-0784(98) 80427-X

(8) Marinov, N. M.; Pitz, W. J.; Westbrook, C. K.; Vincitore, A. M.; Castaldi, M. J.; Senkan, S. M.; Melius, C. F. Combust. Flame 1998, 114, 192. doi: 10.1016/S0010-2180(97)00275-7

(9) Marinov, N. M. Int. J. Chem. Kinet. 1999, 31, 183. doi: 10.1002/ (SICI)1097-4601(1999)31:3<183::AID-KIN3>3.0.CO;2-X

(10) Qin, Z.; Lissianski, V. V.; Yang, H.; Gardiner, W. C.; Davis, S. G.; Wang, H. Proc. Combust. Inst. 2000, 28, 1663. doi: 10.1016/ S0082-0784(00)80565-2 
(11) Carriere, T.; Westmoreland, P. R.; Kazakov, A.; Stein, Y. S.; Dryer, F. L. Proc. Combust. Inst. 2002, 29, 1257. doi: 10.1016/ S1540-7489(02)80155-9

(12) http://web.eng.ucsd.edu/mae/groups/combustion/mechanism. html.

(13) Prince, J. C.; Williams, F. A. Combust. Flame 2012, 159, 2336. doi: 10.1016/j.combustflame.2012.02.012

(14) Wang, H.; You, X.; Joshi, A. V.; Davis, S. G.; Laskin, A.; Egolfopoulos, F.; Law, C. K. USC Mech Version II. HighTemperature Combustion Reaction Model of $\mathrm{H}_{2} / \mathrm{CO} / \mathrm{C}_{1}-\mathrm{C}_{4}$ Compounds. http://ignis.usc.edu/USC_Mech_II.htm (accessed 2007).

(15) Ranzi, E.; Frassoldati, A.; Grana, R.; Cuoci, A.; Faravelli, T.; Kelley, A. P.; Law, C. K. Prog. Energy Combust. Sci. 2012, 38, 468. doi: 10.1016/j.pecs.2012.03.004

(16) Vourliotakis, G.; Skevis, G.; Founti, M. A. Proc. Combust. Inst. 2015, 35, 437. doi: 10.1016/j.proci.2014.06.060

(17) Barbé, P.; Battin-Leclerc, F.; Côme, G. M. J. Chim. Phys. 1995, $92,1666$.

(18) Hughes, K. J.; Turanyi, T.; Clague, A. R.; Pilling, M. J. Int. J. Chem. Kinet. 2001, 33, 513. doi: 10.1002/kin.1048

(19) Hughes, K. J.; Turanyi, T.; Clague, A. R.; Pilling, M. J. http:// garfield.chem.elte.hu/Combustion/mechanisms/metan15.dat.

(20) Rabitz, H.; Kramer, M.; Dacol, D. Annu. Rev. Phys. Chem. 1983, 34, 419. doi: 10.1146/annurev.pc.34.100183.002223

(21) Løvås, T. Combust. Flame 2009, 156, 1348. doi: 10.1016/j. combustflame.2009.03.009

(22) Lu, T. F.; Law, C. K. Proc. Combust. Inst. 2005, 30, 1333. doi: 10.1016/j.proci.2004.08.145

(23) Jiang, Y.; Qiu, R. Acta Phys. -Chim. Sin. 2009, 25, 1019. [蒋 勇, 邱 榕. 物理化学学报, 2009, 25, 1019.] doi: 10.3866/PKU. WHXB20090426

(24) Pepiot-Desjardins, P.; Pitsch, H. Combust. Flame 2008, 154, 67. doi: 10.1016/j.combustflame.2007.10.020

(25) Sun, W.; Chen, Z.; Gou, X.; Ju, Y. Combust. Flame 2010, 157, 1298. doi: 10.1016/j.combustflame.2010.03.006

(26) Luo, Z. Y.; Lu, T. F.; Maciaszek, M. J.; Som, S.; Longman, D. E. Energy Fuels 2010, 24, 6283. doi: 10.1021/ef1012227

(27) Zheng, X. L.; Lu, T. F.; Law, C. K. Proc. Combust. Inst. 2007, 31, 367. doi: 10.1016/j.proci.2006.07.182

(28) Niemeyer, K. E.; Sung, C. J.; Raju, M. P. Combust. Flame 2010,
157, 1760. doi: 10.1016/j.combustflame.2009.12.022

(29) Liu, A. K.; Jiao, Y.; Li, S. H.; Wang, F.; Li, X. Y. Energy Fuels 2014, 28, 5426. doi: 10.1021/ef5002502

(30) Chen, J. Y. Combust. Sci. Technol. 1988, 57, 89. doi: 10.1080/ 00102208808923945

(31) Valorani, M.; Creta, F.; Goussis, D. A.; Lee, J. C.; Najm, H. N. Combust. Flame 2006, 146, 29. doi: 10.1016/j. combustflame.2006.03.011

(32) Lam, S. H. Combust. Sci. Technol. 1993, 89, 375. doi: 10.1080/ 00102209308924120

(33) Maas, U.; Pope, S. B. Combust. Flame 1992, 88, 239. doi: 10.1016/0010-2180(92)90034-M

(34) Wang, Q. D. Acta Phys. -Chim. Sin. 2016, 32, 595. [王全德. 物理化学学报, 2016, 32, 595.] doi:10.3866/PKU. WHXB201512211

(35) Li, R.; Li, S. H.; Wang, F.; Li, X. Y. Combust. Flame 2016, 166, 55. doi: 10.1016/j.combustflame.2015.12.027

(36) Androulakis, I. P.; Grenda, J. M.; Bozzelli, J. W. AIChE J. 2004, 50, 2956. doi: 10.1002/aic.10263

(37) He, K.; Ierapetritou, M. G.; Androulakis, I. P. AIChE J. 2012, 58, 553. doi: 10.1002/aic.12608

(38) Lutz, A. E.; Kee, R. J.; Miller, J. A. Senkin: A Fortran Program for Predicting Homogeneous Gas Phase Chemical Kinetics with Sensitivity Analysis; Sandia National Laboratories: Livermore, CA, 1990; Sandia National Laboratories Report SAND-87-8248.

(39) Li, S. H.; Liu, J. W.; Li, R.; Wang, F.; Tan, N. X.; Li, X. Y. Chem. J. Chin. Univ. 2015, 36, 1576. [李树豪, 刘建文, 李 瑞, 王 繁, 谈宁馨, 李象远. 高等学校化学学报, 2015, 36, 1576.] doi: $10.7503 /$ cjcu20150126

(40) Glarborg, P.; Kee, R. J.; Grcar, J. F.; Miller, J. A. PSR: A FORTRAN Program for Modeling Well-Stirred Reactors; Sandia National Laboratories: Livermore, CA, 1986; Sandia National Laboratories Report SAND-86-8209.

(41) Kee, R. J.; Grcar, J. F.; Smooke, M. D.; Miller, J. A. A Fortran Program for Modeling Steady Laminar One-Dimensional Premixed Flames; Sandia National Laboratories: Livermore, CA, 1985; Sandia National Laboratories Report SAND-85-8240.

(42) Lu, T.; Law, C. K. Prog. Energy Combust. Sci. 2009, 35, 192. doi: 10.1016/j.pecs.2008.10.002

(43) Berkowitz, J.; Ellison, G. B.; Gutman, D. J. Phys. Chem. 1994, 98, 2744. doi: 10.1021/j100062a009 
Supporting Information for Acta Phys. -Chim. Sin. 2016, 32 (7): 1623-1633

doi: 10.3866/PKU.WHXB201604084

\title{
$\mathrm{C}_{1}-\mathrm{C}_{2}$ 燃料燃烧机理的框架简化
}

\author{
李树豪 $^{1} \quad$ 李 瑞 $^{1} \quad$ 郭俊江 $^{2}$ 谈宁馨 $^{2}$ 王 繁 ${ }^{3, *}$ \\ 李象远 $^{2}$ \\ ( ${ }^{1}$ 四川大学空天科学与工程学院, 成都 $610065 ;{ }^{2}$ 四川大学化学与工程学院, 成都 610065 ; \\ ${ }^{3}$ 四川大学原子与分子物理研究所, 成都 610065)
}

\section{Skeletal Kinetic Model Generation for the Combustion of $\mathrm{C}_{1}-\mathrm{C}_{2}$ Fuels}

\author{
LI Shu-Hao $^{1} \quad$ LI Rui $^{1} \quad$ GUO Jun-Jiang $^{2} \quad$ TAN Ning-Xin $^{2} \quad$ WANG Fan $^{3, *}$ \\ LI Xiang-Yuan ${ }^{2}$ \\ ( ${ }^{1}$ School of Aeronautics \& Astronautics, Sichuan University, Chengdu 610065, P. R. China; \\ ${ }^{2}$ School of Chemical Engineering, Sichuan University, Chengdu 610065, P. R. China; \\ ${ }^{3}$ Institute of Atomic and Molecular Physics, Sichuan University, Chengdu 610065, P. R. China)
}

*Corresponding author. Email: wangf44@gmail.com; Tel: +86-28-85403537. 
Table S1 Retained species in the corresponding skeletal mechanisms with the predicted errors of ignition delay time controlled within $10 \%$

\begin{tabular}{|c|c|c|}
\hline Method & Number & Species in skeletal mechanism \\
\hline DRG & 171 & 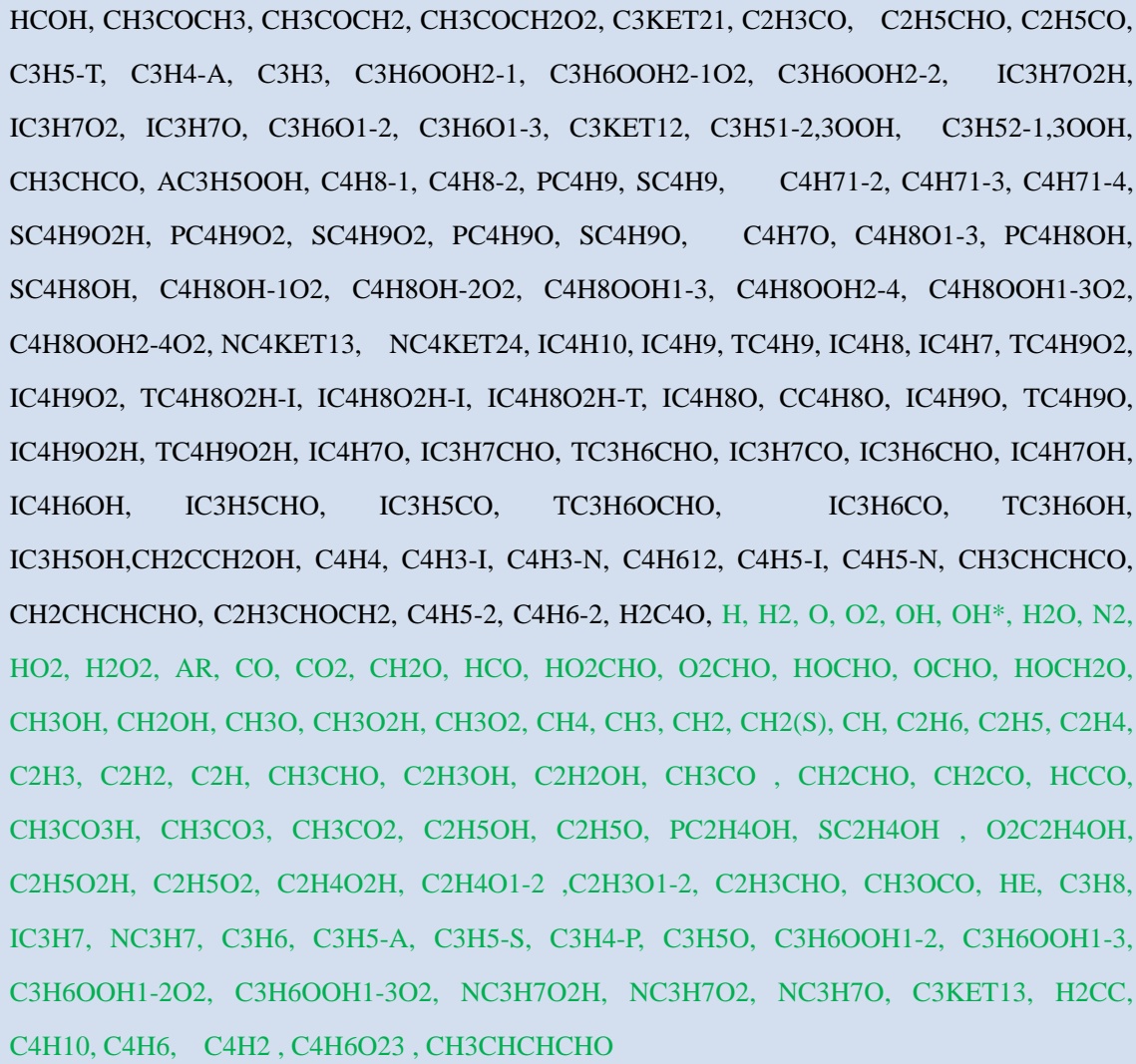 \\
\hline DRGEP & 119 & 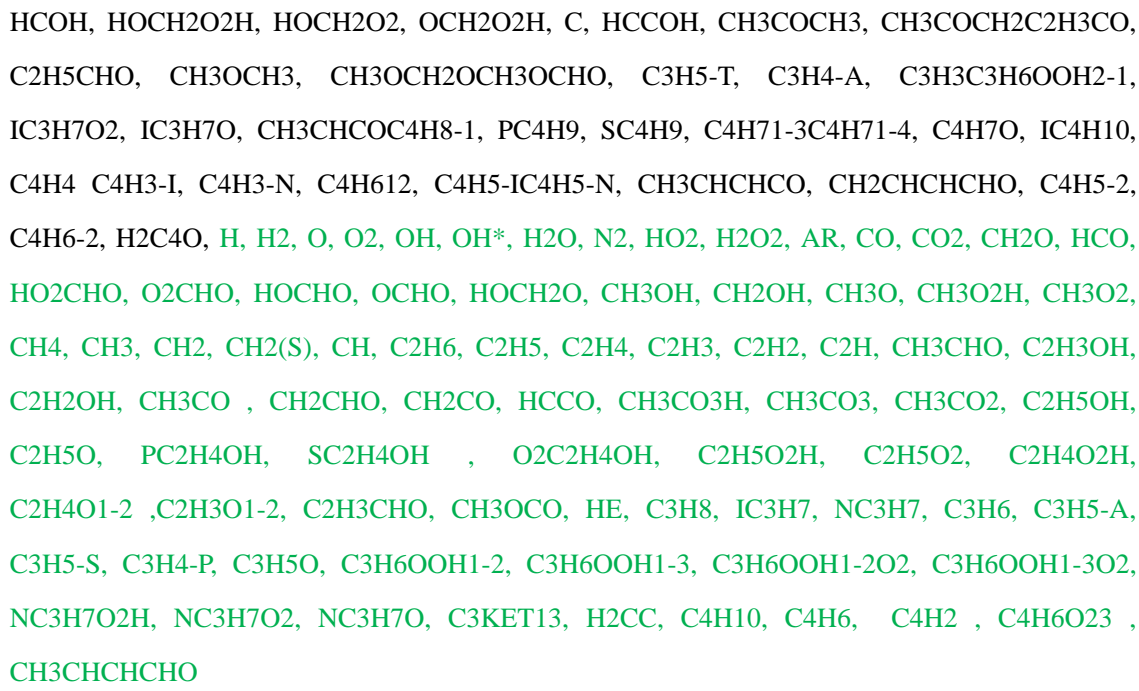 \\
\hline r-DRG & 131 & 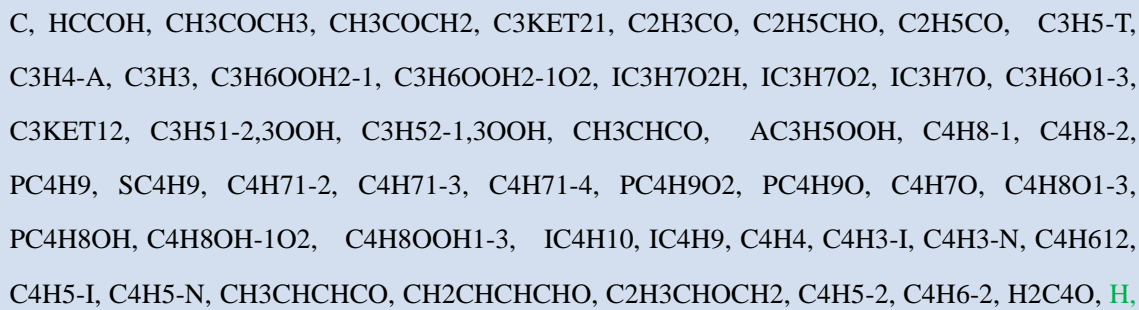 \\
\hline
\end{tabular}




\begin{tabular}{|c|c|c|}
\hline & & 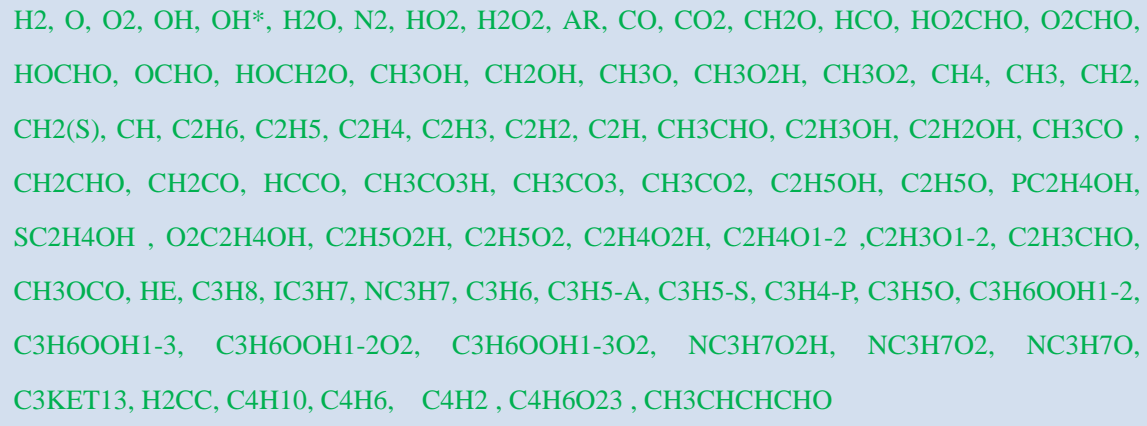 \\
\hline (r-DRG)EP & 85 & 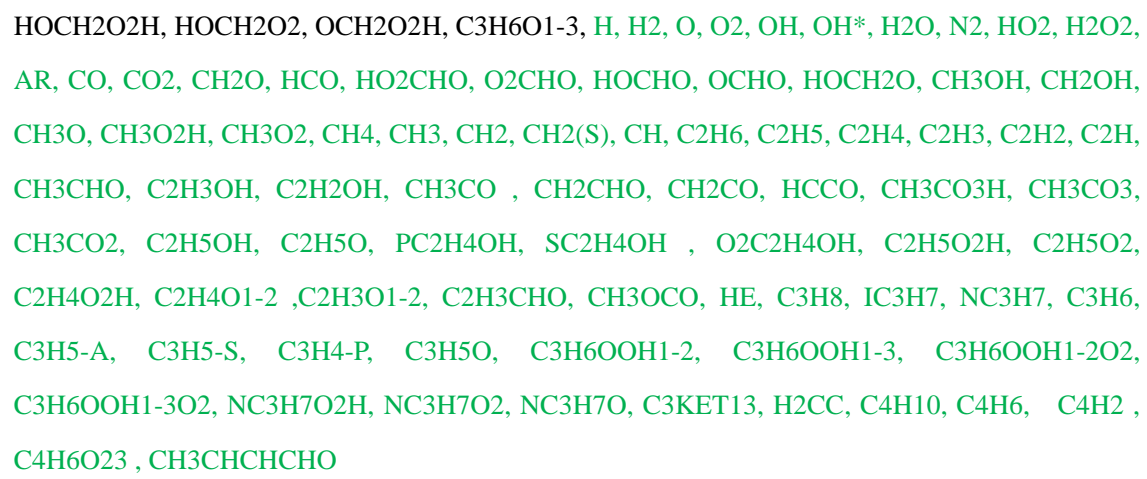 \\
\hline PFA & 176 & 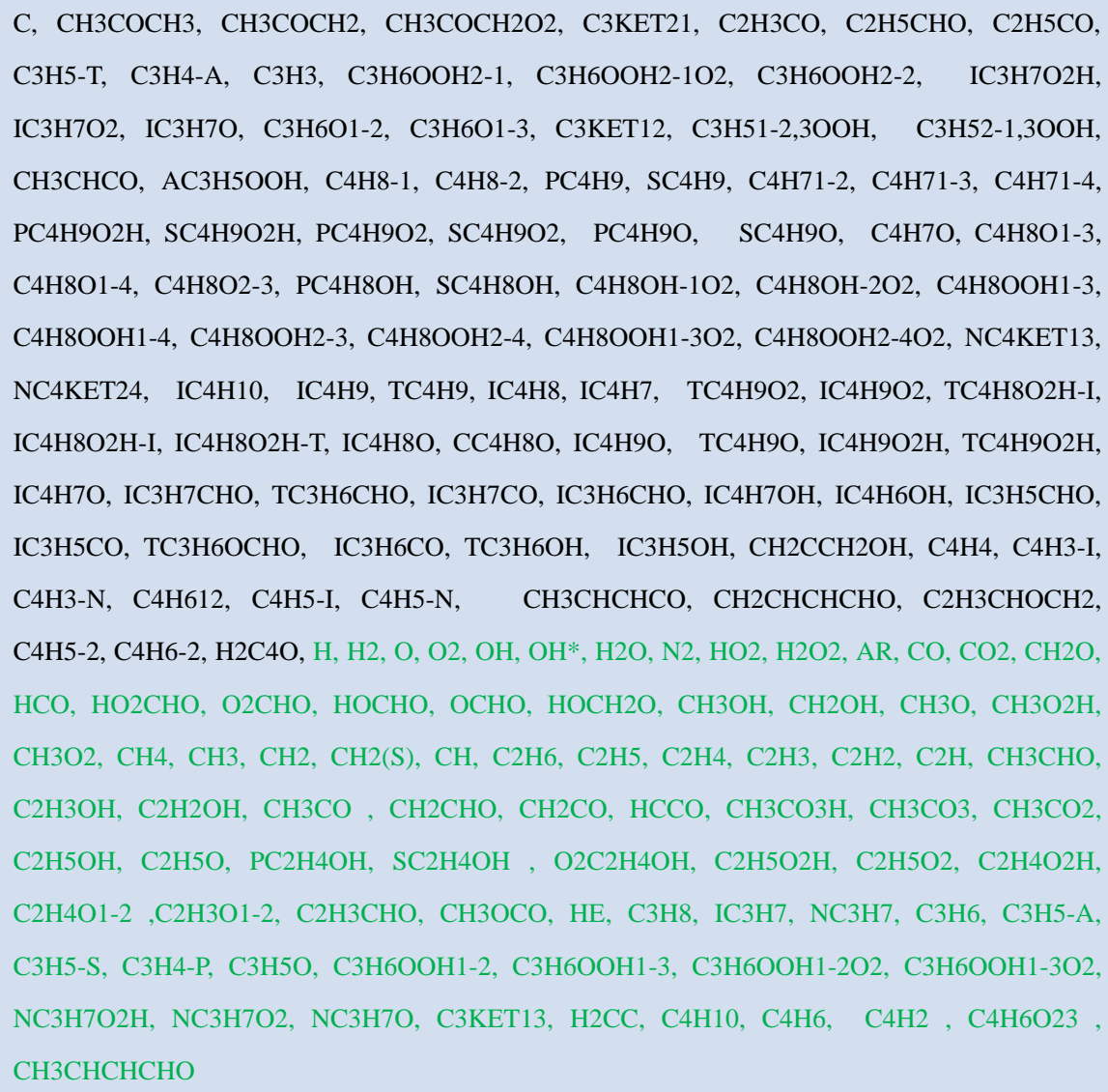 \\
\hline PFAEP & 105 & $\begin{array}{l}\mathrm{HCOH}, \mathrm{HOCH} 2 \mathrm{O} 2 \mathrm{H}, \mathrm{HOCH} 2 \mathrm{O} 2, \mathrm{OCH} 2 \mathrm{O} 2 \mathrm{H}, \mathrm{C}, \mathrm{HCCOH}, \mathrm{CH} 3 \mathrm{COCH} 2, \mathrm{C} 2 \mathrm{H} 3 \mathrm{CO}, \\
\mathrm{CH} 3 \mathrm{OCH} 2 \mathrm{O}, \mathrm{CH} 3 \mathrm{OCHO}, \mathrm{C} 3 \mathrm{H} 5-\mathrm{T}, \mathrm{C} 3 \mathrm{H} 4-\mathrm{A}, \mathrm{C} 3 \mathrm{H} 3, \mathrm{C} 3 \mathrm{H} 6 \mathrm{O} 1-3, \mathrm{CH} 3 \mathrm{CHCO}, \mathrm{C} 4 \mathrm{H} 8-1, \mathrm{PC} 4 \mathrm{H} 9, \\
\mathrm{SC} 4 \mathrm{H} 9, \mathrm{C} 4 \mathrm{H} 7 \mathrm{O}, \mathrm{C} 4 \mathrm{H} 4, \mathrm{C} 4 \mathrm{H} 3-\mathrm{I}, \mathrm{C} 4 \mathrm{H} 3-\mathrm{N}, \mathrm{C} 4 \mathrm{H} 5-\mathrm{I}, \mathrm{CH} 2 \mathrm{CHCHCHO}, \mathrm{H}, \mathrm{H} 2, \mathrm{O}, \mathrm{O} 2, \mathrm{OH}, \mathrm{OH}^{*}, \mathrm{H} 2 \mathrm{O} \text {, } \\
\mathrm{N} 2, \mathrm{HO} 2, \mathrm{H} 2 \mathrm{O} 2, \mathrm{AR}, \mathrm{CO}, \mathrm{CO} 2, \mathrm{CH} 2 \mathrm{O}, \mathrm{HCO}, \mathrm{HO} 2 \mathrm{CHO}, \mathrm{O} 2 \mathrm{CHO}, \mathrm{HOCHO}, \mathrm{OCHO}, \mathrm{HOCH} 2 \mathrm{O}, \\
\mathrm{CH} 3 \mathrm{OH}, \mathrm{CH} 2 \mathrm{OH}, \mathrm{CH} 3 \mathrm{O}, \mathrm{CH} 3 \mathrm{O} 2 \mathrm{H}, \mathrm{CH} 3 \mathrm{O} 2, \mathrm{CH} 4, \mathrm{CH} 3, \mathrm{CH} 2, \mathrm{CH} 2(\mathrm{~S}), \mathrm{CH}, \mathrm{C} 2 \mathrm{H} 6, \mathrm{C} 2 \mathrm{H} 5, \mathrm{C} 2 \mathrm{H} 4, \\
\mathrm{C} 2 \mathrm{H} 3, \mathrm{C} 2 \mathrm{H} 2, \mathrm{C} 2 \mathrm{H}, \mathrm{CH} 3 \mathrm{CHO}, \mathrm{C} 2 \mathrm{H} 3 \mathrm{OH}, \mathrm{C} 2 \mathrm{H} 2 \mathrm{OH}, \mathrm{CH} 3 \mathrm{CO}, \mathrm{CH} 2 \mathrm{CHO}, \mathrm{CH} 2 \mathrm{CO}, \mathrm{HCCO},\end{array}$ \\
\hline
\end{tabular}




\begin{tabular}{|c|c|c|}
\hline & & $\begin{array}{l}\mathrm{CH} 3 \mathrm{CO} 3 \mathrm{H}, \mathrm{CH} 3 \mathrm{CO} 3, \mathrm{CH} 3 \mathrm{CO} 2, \mathrm{C} 2 \mathrm{H} 5 \mathrm{OH}, \mathrm{C} 2 \mathrm{H} 5 \mathrm{O}, \mathrm{PC} 2 \mathrm{H} 4 \mathrm{OH}, \mathrm{SC} 2 \mathrm{H} 4 \mathrm{OH}, \mathrm{O} 2 \mathrm{C} 2 \mathrm{H} 4 \mathrm{OH} \text {, } \\
\mathrm{C} 2 \mathrm{H} 5 \mathrm{O} 2 \mathrm{H}, \mathrm{C} 2 \mathrm{H} 5 \mathrm{O} 2, \mathrm{C} 2 \mathrm{H} 4 \mathrm{O} 2 \mathrm{H}, \mathrm{C} 2 \mathrm{H} 4 \mathrm{O} 1-2 \text {, } 22 \mathrm{H} 3 \mathrm{O} 1-2, \mathrm{C} 2 \mathrm{H} 3 \mathrm{CHO}, \mathrm{CH} 3 \mathrm{OCO}, \mathrm{HE}, \mathrm{C} 3 \mathrm{H} 8, \\
\mathrm{IC} 3 \mathrm{H} 7, \mathrm{NC} 3 \mathrm{H} 7, \mathrm{C} 3 \mathrm{H} 6, \mathrm{C} 3 \mathrm{H} 5-\mathrm{A}, \mathrm{C} 3 \mathrm{H} 5-\mathrm{S}, \mathrm{C} 3 \mathrm{H} 4-\mathrm{P}, \mathrm{C} 3 \mathrm{H} 5 \mathrm{O}, \mathrm{C} 3 \mathrm{H} 6 \mathrm{OO} 1-2, \mathrm{C} 3 \mathrm{H} 6 \mathrm{OH} 1-3, \\
\mathrm{C} 3 \mathrm{H} 6 \mathrm{OOH} 1-2 \mathrm{O} 2, \mathrm{C} 3 \mathrm{H} 6 \mathrm{OH} 1-3 \mathrm{O} 2, \mathrm{NC} 3 \mathrm{H} 7 \mathrm{O} 2 \mathrm{H}, \mathrm{NC} 3 \mathrm{H} 7 \mathrm{O} 2, \mathrm{NC} 3 \mathrm{H} 7 \mathrm{O}, \mathrm{C} 3 \mathrm{KET} 13, \mathrm{H} 2 \mathrm{CC}, \\
\mathrm{C} 4 \mathrm{H} 10, \mathrm{C} 4 \mathrm{H} 6, \mathrm{C} 4 \mathrm{H} 2, \mathrm{C} 4 \mathrm{H} 6 \mathrm{O} 23, \mathrm{CH} 3 \mathrm{CHCHCHO}\end{array}$ \\
\hline Intersection & 81 & 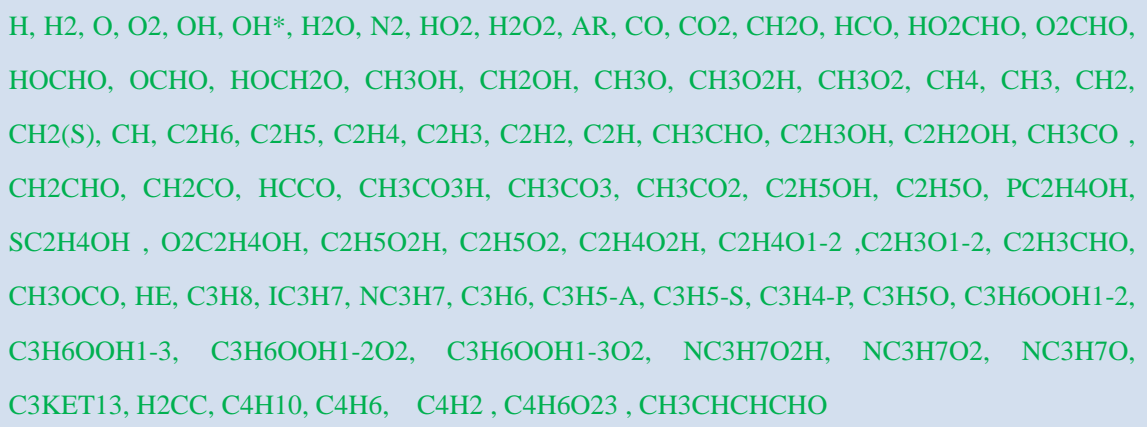 \\
\hline
\end{tabular}

